\title{
Las batallas de Atapuerca y la (re)escritura novelesca de la historia
}

\author{
Maximiliano A. Soler Bistué
}

Universidad de Buenos Aires / Secrit (Conicet)

max soler@yahoo.com

https://orcid.org/OOOO-OOO2-7745-I948

Received I2/o7/2OI9; accepted I6/IO/2OI9

DOI: https://doi.org/IO.7203/MCLM.7.I5596

\section{The battles of Atapuerca and the fictional (re)writing of History}

Abstract

This work highlights and describes the specific way in which fictional discourse in Spanish gradually took shape and developed in the rewriting of history in the first half of the I3th century. The battle of Atapuerca (IO54) is a milestone in the history of the Kingdom of Navarre. Since its first historiographical version preserved in the Historia silense (c. III8II26), the account of the battle of Atapuerca underwent modifications, amplifications and several recasts in its extensive dispersion in time and space. In the first place, the work presents a comparison between different Latin versions (mainly the Silense, the Chronicon mundi and De rebus Hispaniae) and several Castilian versions (the Versión crítica de la Estoria de España, the Crónica sanchina, the Crónica de Castilla and the Crónica general de 1344) of the battle of Atapuerca. Secondly, a detailed analysis of a late version of the battle is carried out taking into account the evolution of narrative prose in medieval Spanish. This version adopts the typical narrative forms of the fazaña, a minor Castilian legal genre. The work focuses at this point on the peculiar intersection between the legal mould provided by this short narrative form and the traditional historiographic matter. In the treatment of historical matter and in the peculiar presentation of motifs and characters in this episode, the fazaña shows striking features that many critics have identified as fictional or even novelesque.

KEYWORDS

Kingdom of Castile; Kingdom of Navarre; medieval historiography; history of Spanish prose; medieval chronicles; semiotics; discourse analysis; narrative; fiction; political ideology in Middle Ages; nobility

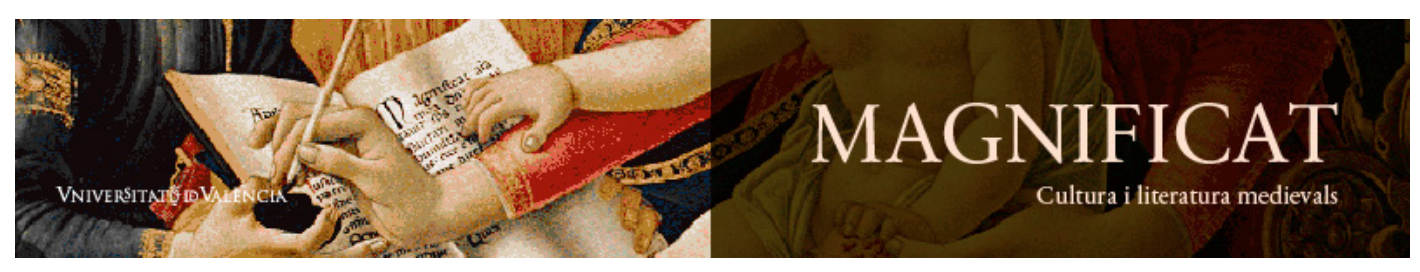

Magnificat Cultura i Literatura Medievals 7, 2020, I-43. http://ojs.uv.es/index.php/MCLM

ISSN $2386-8295$ 
Resumen

Este trabajo pone de relieve y describe el modo en que el discurso ficcional en lengua castellana se gestó paulatinamente en el proceso de reescritura de la historia en la primera mitad del siglo XIII. La batalla de Atapuerca (IO54) constituye un hito en la historia del reino de Navarra. Desde su primera versión historiográfica conservada en la Historia silense (c. III8II26), el relato de la batalla de Atapuerca sufrió modificaciones, amplificaciones y refundiciones en su extensa dispersión en el tiempo y el espacio. En un primer momento, el trabajo presenta una comparación entre distintas versiones latinas (fundamentalmente la Silense, el Chronicon mundi y De rebus Hispaniae) y castellanas (la Versión crítica de la Estoria de España, la Crónica sanchina y la Crónica de Castilla hasta la Crónica general de 1344) de la batalla de Atapuerca. En un segundo momento, atendiendo a la evolución de la prosa narrativa en lengua castellana, se lleva a cabo un análisis de una versión tardía del enfrentamiento que adopta las formas narrativas propias de la "fazaña". El trabajo se centra en este punto en el singular cruce entre el molde jurídico que proporciona esta forma narrativa breve y la materia historiográfica tradicional. En el tratamiento de la materia histórica y en la peculiar presentación de motivos y personajes que se observa en este episodio, se manifiestan llamativos rasgos que la crítica ha identificado como novelescos.

\section{Palabras clave}

Reino de Castilla; Reino de Navarra; historiografía medieval; historia de la prosa castellana; crónicas medievales; semiótica; análisis del discurso; narrativa; ficción; ideología política en la Edad Media; nobleza

Maximiliano A. Soler Bistué. 2020. 'Las batallas de Atapuerca y la (re)escritura novelesca de la historia', Magnificat Cultura i Literatura Medievals, 7: I-43, DOI: https://doi.org/IO.7203/ MCLM.7.I5596 (сc) Br

Este trabajo se inscribe en el marco del proyecto PICT 2OI4 2038 "La narrativa histórica medieval de inspiración nobiliaria: edición y estudio formal e ideológico” dirigido por el Dr. Leonardo Funes, radicado en el Instituto de Investigaciones Bibliográfica y Crítica Textual (Seminario de Edición y Crítica Textual “Dr. Germán Orduna”) dependiente del Consejo Nacional de Investigaciones Científicas y Técnicas y financiado por la Agencia Nacional de Promoción Científica y Técnica de la Secretaría de Ciencia y Técnica de la República Argentina.

\section{TABLA DE CONTENIDOS}

I Introducción - 3

2 Precisiones metodológicas. Historiografía y semiótica -5

3 La batalla de Atapuerca en la historiografía latina - 8

4 La batalla de Atapuerca en la historiografía castellana - I5

5 De la crónica a la fazaña. Una historia singularmente amplificada -20

5.I Estructura narrativa de la fazaña - 23

5.2 Recursos y procedimientos -23

$5 \cdot 3$ La muerte del rey -25

5.4 A rey muerto, rey puesto. Historiografía y profanación - 28

$5 \cdot 5$ Estorias nobiliarias, escritura novelesca - 30

6 Historiografía, semiótica, ideología $-3^{2}$

${ }_{7}$ Conclusiones - 35

8 Agradecimientos - 37

${ }_{9}$ Obras citadas $-3^{8}$ 


\section{ə*⿻丷木}

Una fazaña suelen las gentes retraer, non yaze en escripto, es malo de creer, si es verdat o non, yo non y de qué fer, mager, non la quiero en olvido poner.

Libro de Alexandre, c. 2305

\section{Introducción}

E desarrollo y la consolidación de la prosa en lengua castellana que tuvo lugar entre mediados y fines del siglo XIII encontró en la historiografía un espacio textual tan concreto como singular. El interés por los textos cronísticos durante esta fase de la Baja Edad Media se manifiesta en la considerable cantidad de testimonios conservados en Castilla, lo que hace de la historiografía castellana de los siglos XIII y XIV un corpus ineludible para comprender la evolución de la prosa narrativa hispano-medieval y, en virtud de la variedad y riqueza de recursos, estrategias y subgéneros, un objeto valioso en sí mismo para la investigación literaria. Las crónicas de mediados a fines del Doscientos en especial constituyeron un verdadero laboratorio de experimentación para la prosa narrativa en lengua castellana.

Por otra parte, los patrones de configuración del discurso histórico que en esos textos se ensayaron y templaron involucraron aspectos técnicos decisivos para el ulterior desarrollo de la prosa narrativa (y eventualmente de la ficción) a lo largo de la siguiente centuria. Desde luego, los diversos proyectos historiográficos que rivalizaron y se sucedieron en el largo siglo de emergencia y consolidación de la prosa historiográfica en Castilla fueron de naturaleza muy diversa: desde las Estorias alfonsíes (caracterizadas por una concepción universalista que planteaba una historia global de todos los señoríos del reino desde su primer poblamiento [Funes I997]) y la crónica real (que ajustaba su relato a los sucesos de un reinado específico), hasta la crónica particular (centrada en los hechos de la vida de un personaje que orientaba el relato de la historia). Más allá de sus propósitos específicos, cada uno de estos proyectos historiográficos volvió sobre una misma materia cronística, que supieron reproducir con mayor o menor grado de fidelidad respecto de sus fuentes o bien reelaboraron a conciencia y sensiblemente. Tal es el caso, por ejemplo, de motivos legendarios como el de los jueces de Castilla, la materia cidiana, o el episodio de la mora Zaida durante el reinado de Alfonso VI. ${ }^{\mathrm{I}}$

I. Con respecto al derrotero de materia legendaria en la historiografía castellana, pueden consultarse los trabajos de Georges Martin (1992) y Alberto Montaner (2005) que remontan su estudio a la historiografía latina y árabe en el caso de este último. Marta Lacomba (2009), por su parte, ha llevado a cabo un detenido análisis del tratamiento de la materia cidiana en tres crónicas de fines del Doscientos. Fernando Gómez Redondo (2OI3) también ha dedicado un extenso estudio a las variaciones de la leyenda de Los siete infantes de Lara desde la materia a su prosificación y configuración ejemplar en diversas crónicas abarcando un arco que se extiende desde la Estoria de España hasta la Crónica de 1344. Como se podrá constatar en los apartados siguientes y dejando de lado el corpus arábigo, compartimos buena parte de este derrotero por las crónicas hispánicas, aunque con el propósito de señalar las peculiaridades que se expresan en un testimonio tardío de los hechos de Atapuerca que en este caso se presenta bajo formas que lo emparientan al relato histórico novelizado, la leyenda o la ficción. 
En esta oportunidad, nos centraremos en un episodio en particular, la batalla de Atapuerca librada el I de septiembre de I054. Este enfrentamiento desplazó hacia el este la frontera entre Castilla y Navarra, consolidó el reino de Fernando I como potencia en la península y señaló el comienzo de la expansión de sus dominios hacia el este y hacia el sur (Besga Marroquín 20o9; García González 2008). Fue esta la primera guerra fratricida de que se guarde registro y, dado que Castilla era condado cuando Fernando se enfrentó en Tamarón con Bermudo III de León, también el primer enfrentamiento entre reinos hispano cristianos. Las referencias a este trágico episodio de la historia de la conformación de los reinos cristianos en la Península Ibérica tiene una arraigada y profusa tradición historiográfica: encontramos referencias en crónicas latinas, castellanas, navarras y aragonesas pero también menciones en textos jurídicos como el Becerro de las behetrías (I353) o en un poema épico tardío como Mocedades de Rodrigo (c. I36o).

Desde la primera versión conservada en la Historia silense (c. III8-II26), el relato de la batalla sufrió modificaciones, amplificaciones y refundiciones en su extensa dispersión en el tiempo y el espacio. Nuestro propósito no será determinar lo que efectivamente ocurrió en el campo de batalla, precisar el grado de historicidad ni confirmar o refutar lo transmitido por un testimonio en particular ("si es verdat o non, yo non y de qué fer"). El objetivo de este trabajo consiste, en cambio, en poner de relieve los patrones de configuración del relato en textos historiográficos castellanos de comienzos a mediados del siglo XIV atendiendo tanto a las variaciones del relato (su contenido) así como a su inscripción (su forma de expresión), a las modalidades e inflexiones del discurso historiográfico confrontando las versiones tardías del episodio de Atapuerca.

En este sentido, el marco general de este estudio es la evolución de la prosa historiográfica en lengua castellana con especial interés en las crónicas post-alfonsíes; su horizonte es algo más específico: la escritura de corte nobiliario identificable tanto por ciertos rasgos formales en la construcción del relato histórico como por contenidos idiosincrásicos e ideológicos (función de la nobleza en relación con el rey, conducta modélica del monarca, atributos específicos de estos agentes, concepción de la monarquía). Es por ello que los testimonios latinos de la narración de la batalla de Atapuerca, a pesar de ser antecedentes ineludibles, no serán el principal objeto de análisis en esta oportunidad.

El punto de fuga que orienta el estudio comparativo que aquí presento lo constituye una versión tardía de este enfrentamiento incluida en el manuscrito 43I de la Biblioteca Nacional de España ${ }^{2}$. Las variantes que presenta este testimonio son sorprendentes si tenemos en cuenta la relativa estabilidad tanto de los temas y tópicos como de la estructura narrativa básica del episodio hasta el momento de la puesta por escrito de esta versión.

Las diferencias entre este último caso y el resto del corpus son de distinto tipo y, en términos generales, podrían describirse del siguiente modo: en primer lugar, con respecto al género, se trata de una fazaña, esto es, de un texto narrativo breve de carácter jurídico vinculado en sus orígenes al

2. Este códice dataría de la segunda mitad del siglo XIV, muy probablemente entre I360 y I380, y constituye uno de los mayores testimonios de un intento de formalización escrita, a mediados del siglo XIV, del derecho señorial nunca fijado oficialmente en Castilla. Reúne el Libro de los fueros de Castiella, redactado a mediados del siglo XIII, la primera tentativa que se conserva de redactar el derecho señorial en su conjunto, anterior, incluso, a la versión conservada del Fuero Viejo (I356). En segundo lugar, se incluyen las Devisas que han los señores en sus vasallos, obra privada y anónima del siglo XIII y acaso la más antigua de las redacciones breves del derecho señorial. En tercer lugar, el llamado pseudoOrdenamiento de Nájera II, texto que refleja la más antigua fase de redacción de lo que sería el Fuero Viejo conservado. El testimonio incluye además de estos textos legales, una copia del primer testamento de Alfonso X, una versión tardía de la leyenda de la Blasfemia del Rey Sabio y una colección de fazañas que dataría de principios del reinado de Pedro I, no antes de I353. Es en esta colección final donde se recopila la singular versión de la batalla de Atapuerca que nos interesa en esta oportunidad. 
derecho consuetudinario en el que puede o no haber una sentencia y en el que prima la organización narrativa con un planteamiento rápido de la intriga, muy similar al exemplum; en segundo lugar, en cuanto a su contexto inmediato, el episodio de la batalla se presenta en este caso como un fragmento historiográfico aislado sin conexión aparente con otros sucesos del reino anteriores o posteriores y que (en virtud de la naturaleza jurídica de este tipo textual y del resto de los textos incluidos en esta colección y en el códice) podría fungir como antecedente, es decir, como principio jurídico rector para situaciones o casos análogos; en cuanto a sus aspectos formales, pueden observarse diversas modificaciones en la construcción del relato: por un lado, se incluyen ciertos detalles y elementos que no encontramos en versiones anteriores o posteriores (nombres propios, un peculiar uso del discurso directo, ciertas acciones de los personajes) al tiempo que la acción propiamente dicha se recorta contra un fondo histórico reducido a su mínima expresión; finalmente, la estructura narrativa de este relato se ha visto notablemente modificada: se han suprimido secuencias enteras, otras se han alterado y el conflicto principal (o núcleo del relato) se ha visto desplazado para centrarse, más que en las vicisitudes históricas de los reinos involucrados en el conflicto, en dos hechos puntuales: la pérdida de heredades de algunos nobles y la muerte del rey García III de Navarra en el campo de batalla. Examinaremos detenidamente la versión de la batalla de Atapuerca incluida en el manuscrito 43I cuya singularidad podremos apreciar en su justa medida únicamente si consideramos su tradición previa. Como adelanté más arriba, pasaré revista muy sucintamente a los hitos más importantes de la historiografía latina que incluyen este episodio y me detendré en un análisis comparativo de los textos castellanos de la segunda mitad del siglo XIII y comienzos del XIV, antecedentes todos ineludibles, para dar lugar finalmente a un comentario detallado de nuestra versión.

\section{${ }_{2}$ Precisiones metodológicas. Historiografía y semiótica}

L Inés Fernández-Ordóñez señaló oportunamente que existen dos grandes tendencias en la investigación historiográfica: la que ha hecho de la crítica textual un requisito previo e indispensable para sentar los cimientos de la interpretación de los diversos textos, sin por ello renunciar a ella; por otro, aquella que se centra en el análisis discursivo de los textos historiográficos, bien acercándolos a la literatura, bien poniéndolos en relación con el marco socio-histórico en que fueron creados (2OOO-200I: 283). Dentro de esta última línea de investigación, cabe reconocer una perspectiva que, teniendo en cuenta tanto sus singularidades formales (lo propio de la literatura) como sus marcos de producción (lo socio-histórico), presta especial atención a la dimensión semiótica del discurso historiográfico. Esta perspectiva semiótica en el estudio de la historiografía medieval ha sido presentada por Georges Martin como

un point de vue sémiotique sous lequel le discours des historiens médiévaux serait enfin abordé dans sa structure de signe. Cette entreprise ne peut faire l'économie de prendre en compte l'univers sémiotique dans lequel l'historiographe pensait sa pratique, l'imaginaire sémiotique de l'historiographie (Martin 1997: 43-44).

Una perspectiva semiótica permite no solo precisar el sentido profundo o la significación del texto sino también considerar los usos que de un término específico o un episodio historiográfico se llevan a cabo a partir de una reactualización o reelaboración de los mismos. Esto se debe a que, en virtud del sistema hermenéutico medieval que consideraba múltiples sentidos en la interpretación 
del texto, el proceso de significación figural hace del referente un nuevo signo dado que es a la vez significado y significante. Este proceso general de significación tiene, lógicamente, implicaciones en la escritura de la historia. El cronista medieval debía asegurar la transparencia del lenguaje, no alterar la relación entre el orden divino del mundo (símbolo espiritual) y el texto histórico (signo lingüístico) al que abocaba su tarea. Así, la escritura historiográfica consistía en mediar entre estos dos sistemas semióticos, entre estos dos lenguajes: por un lado, el orden espiritual (dimensión trascendente) y, por otro, el proceso de realización y actualización del Verbo divino (el mundo material en el que se encuentra la materia histórica), de modo tal que esta adquiere su plena significación únicamente en aquel. Este imaginario semiótico medieval se fundamenta y encuentra su realización última en la interpretación de las Escrituras o de las cosas que a su vez participan del signo universal en tanto significante, toda vez que Dios ordena el mundo de acuerdo a un sentido, una Verdad que se expresa en el Verbo (Escritura y mundo) (Dahan r999: 239 y ss., 325-350). Asimismo, este imaginario da lugar en la práctica a una multiplicidad de dispositivos y recursos técnicos que fundamentaban tanto la creencia como la enmienda del Texto. Ahora bien, el mundo (y las cosas que constituyen el objeto primordial de la historiografía) no es mera aparición fantasmática, imitación caída del Verbo, ya que, muy por el contrario, este se actualizaba en su manifestación fenoménica. Tal y como ha señalado Georges Martin, en el marco de la historiografía de los reinos, la instancia semiótica de mediación dominante se ubica en la figura del rey que significa, dado que es principio rector del orden mundano y a la vez símbolo del orden verdadero del Verbo, el mundo y Dios (Martin r997: 54). Es por ello que la historia (como "crónica del mundo" o estoria de los hechos de un reino) se organiza en torno a la figura del monarca que se constituye en el principio ordenador del relato. De este modo, la figura del rey ordena, hacia el interior del texto, el sistema de significación que se despliega en el discurso histórico; y al mismo tiempo, en tanto acto comunicativo, esta figura central hace posible, como destinatario, la labor del historiador: conservar y transmitir los hechos del pasado.

Ahora bien, este imaginario semiótico medieval habilita la consideración de la proyección de la escritura historiográfica al presente de su enunciación. La escritura de la historia se fundamenta en un acontecimiento o bien en un texto previo, en una fuente. La materia de la que parte el cronista contiene y transmite una significación general socialmente aceptada y compartida ("batalla de Atapuerca”, por ejemplo) y se sustenta en un conjunto de formas (imágenes, agentes, atributos y acciones; a saber, para el caso que nos ocupa, "batalla", "rey García III", "rey Fernando I", "envidia", etc.). En cada reescritura, el cronista lleva a cabo una reelaboración del pasado (de la cosa o del texto) en virtud de un reordenamiento de esas formas arquetípicas. Ahora bien, esa reelaboración, en tanto representación, construye su objeto mediante la selección, síntesis, amplificación o supresión de esas formas lo cual implica necesariamente una concepción de ese objeto inherente al acto de escritura de la historia. Y es precisamente esta concepción de los hechos la que imprime en el discurso historiográfico la marca de su presente de enunciación, es decir, la inscripción de la historia en el texto histórico.

La teoría historiográfica no desconoce, desde luego, la problemática y el impacto del denominado Giro Lingüístico y del paradigma postestructuralista en la escritura de la historia. ${ }^{3}$ Pero no es a la correspondencia con los acontecimientos o la fiabilidad de las fuentes a lo que se ha abocado nuestro trabajo, sino a las formas específicas del discurso histórico y a la significación de las variantes de un episodio historiográfico en particular. Desde luego, la tarea del historiador

3. Para una exposición crítica de esta problemática desde la teoría historiográfica, véase Ankersmitt 2OI4, especialmente los capítulos "Representación histórica" (2OI4: I9I-243) e "Historiografía y posmodernismo" (2OI4: $35^{2-460) .}$ 
será la de indagar en las causas y consecuencias efectivas que dieron lugar a esos acontecimientos pero el análisis del discurso historiográfico requiere poner en consideración la perspectiva desde la cual se configuran esas causas y consecuencias y que está implicada en el relato de la historia. Esa perspectiva es el punto de vista del relato histórico que se constituye en grado cero en el marco de ese entramado narrativo pero que difícilmente puede considerarse desinteresado, aséptico o neutral. El discurso del historiador no solo remite a un referente extratextual; también convoca los afectos y pasiones involucrados en los acontecimientos históricos y transfiere la significación de su relato a un afuera del texto que no se agota en ese referente. El cronista medieval fue plenamente consciente de que su tarea era una forma válida y eficaz de intervenir en el presente y de sentar modelos de acción para el futuro.

El problema del anacronismo salta a la vista, tanto como proyección del presente en el pasado como en su sentido inverso. Sin embargo, desatender esta singular dialéctica entre texto y contexto que no se reduce a una relación referencial, de correspondencia sin más entre el discurso y lo real, puede conducir a un problema no menor que es el de suprimir la subjetividad inscrita en el acto de enunciación en la escritura de la historia. Tal y como ha observado Dominick LaCapra:

La noción misma de anacronismo, aunque tenga ciertos usos obvios pero significativos, puede resultar superficial en la medida en que distrae la atención del intrincado proceso por el cual las formas más antiguas son regeneradas o reafirmadas con diferencias más o menos significativas a lo largo del tiempo. Podríamos aventurarnos a decir que los viejos problemas nunca mueren por completo. Tienden a regresar como lo reprimido (20II: 54).

Este último proceso de regeneración y reafirmación de formas antiguas es lo que se pone de relieve en las distintas versiones de la batalla de Atapuerca. Cada reelaboración recupera el sentido literal del episodio, reconfigura las formas elementales del relato que permiten reconocerlo, y se monta así a un sistema de significación previo pero sin anular su sentido "literal” (histórico). Ahora bien, ese sistema no permanece inalterado dado que en cada reelaboración se incorpora una serie de significaciones explicables no tanto por la singularidad de la materia tratada sino más bien por el contexto de producción de cada versión. Estas significaciones no responden necesariamente a una modificación del contenido: a veces solo basta con romper el lazo que articulaba temporal o causalmente los hechos transmitidos en las versiones previas. El quiebre en la disposición de determinadas acciones, el inesperado protagonismo que adquieren personajes menores o la eliminación de secuencias y episodios son todas operaciones que llevan a inscribir el motivo de la batalla de Atapuerca en una nueva configuración que requiere, en consecuencia, atender al contexto social, político y cultural de cada proyecto historiográfico. El análisis de las formas concretas bajo las cuales se presenta en cada caso la batalla de Atapuerca supone considerar no solo las estructuras de interpretación disponibles al momento de composición sino también los efectos de sentido que cada texto proyecta a futuro en un momento histórico singular.

El corpus historiográfico latino y castellano constituye la base de comparación necesaria para evaluar las singularidades temáticas y formales de la versión que transmite la fazaña. Las versiones cronísticas de la batalla de Atapuerca son asimismo indispensables para recabar los diversos elementos del discurso objeto de comparación: los motivos y temas pero también sus recursos y estrategias discursivas; sus procedimientos formales y su estructura narrativa; su punto de vista y su ideología historiográfica y política; el imaginario que nutre estas representaciones así como la estructura lógico-causal implicada en el relato. Estos aspectos solo pueden ponerse de relieve a partir de una perspectiva especialmente atenta a la particular dialéctica entre texto y contexto histórico-cultural que es lo que constituye en definitiva la dimensión semiótica del discurso historiográfico. 
Este cotejo no solo es un recorrido necesario para ponderar adecuadamente las operaciones que hacia fines de la Edad Media y en Castilla rigen la escritura de la historia, sino que proporciona además un caso de estudio específico y especialmente productivo a través del cual se pone de manifiesto la relación dinámica que una comunidad textual determinada establece con el pasado y con su presente (Maddox I986: 6). La reescritura de un episodio historiográfico concreto en un contexto manuscrito no cronístico da cuenta asimismo de una circulación de saberes y discursos que explora modalidades inusuales en la prosa castellana. En esas inflexiones y cruces entre la historia, el derecho y la política comienza a manifestarse, tal y como han observado distintos estudiosos, una escritura novelesca. ${ }^{4}$

En las fazañas castellanas tardías (de las que el manuscrito 43 es el principal y más nutrido archivo) se expanden ciertos detalles en la exposición de los hechos del caso a juzgar a punto tal que el relato (en un origen, mero fundamento de la decisión judicial) se asemeja en sus formas más a la anécdota historiográfica que encontramos en crónicas como la * Historia hasta 1288 dialogada, la denominada Estoria cabadelante o la Crónica particular de San Fernando que a una disposición jurídica. La relativa autonomía de estas formas narrativas breves (dado que carecen de marcos que las vinculen formalmente con un discurso más amplio), su carácter indicial y elíptico y su potencia expresiva constituyen la impronta novelesca que en más de una oportunidad se le ha atribuido a este tipo de textos. Es, pues, el surgimiento de la escritura novelesca en prosa hacia comienzos y mediados del siglo XIV lo que se insinúa en estas formas narrativas breves y lo que nos interesa examinar especialmente en el relato de la batalla de Atapuerca.

\section{La batalla de Atapuerca en la historiografía latina}

El silense. ${ }^{5}$ Y no es solo el más antiguo relato de este episodio, sino también la fuente en la que abrevan otras crónicas latinas posteriores: el Liber Chronicorum (c. II2O-II42; "Iste preliando [Fredenandus I] in Ataporca interfecit fretrem suum Garseanum Regem, et accepit regnum eius Era MLXV"; Sánchez Alonso ed. I924: 74) del obispo Pelayo y el aragonés Liber regum (c. I2OO; Serrano y Sanz ed. I9I9: 209-2IO y 2I2) apenas mencionan la batalla y se atienen más a sus consecuencias; la Chronica Naierensis (c. II73-II94) la sigue muy de cerca con alguna variante menor (Estévez Sola ed. 2003: I62-I63; Libro III.5) y el Chronicon Mundi (c. I236-I238) de Lucas de Tuy que también reproduce casi al pie de la letra esta misma versión de los hechos (Falque ed. 2003: 283-284; Libro IV, 5o, líneas 28-34).

El texto de la Historia silense enlaza los sucesos de la batalla de Atapuerca con otros anteriores, como la repartición de los reinos de Sancho Garcés entre sus cuatro hijos o la batalla de Tamarón

4. Bermejo Cabrero (I972) ha sido uno de los primeros en llamar la atención sobre la peculiar relación entre literatura, derecho e historiografía que se despliega en estos textos jurídicos. Fernando Gómez Redondo, por su parte, ha señalado en su comentario a este tipo textual jurídico característico de Castilla que "la fazaña puede acabar convirtiéndose en una verdadera pieza literaria” (1998: 92) como efectivamente puede apreciarse en la célebre fazaña del hombre y la serpiente incluida en la colección final del Fuero de Navarra.

5. Tanto la denominación como la autoría y fecha de esta crónica han sido recientemente puestas en discusión. Georges Martin (20I2a) ha propuesto como autor de la Historia legionensis (y no silensis) a Ordoño Sisnández, canónigo de San Isidoro de León entre iпı y пз33, lo que lo lleva a proponer una fecha temprana de composición del texto, entre III8 y пг26 (20I2a: 24). Por su parte, Patrick Henriet (20I2), si bien mantiene la denominación de Silense, ha propuesto una figura de autor miembro de la diócesis de Sahagún. Sin ánimo de decidir la cuestión, nos referiremos convencionalmente a esta crónica como Historia silense. 
(IO37) contra Bermudo III, rey de León. Esta crónica destaca especialmente las desavenencias previas al enfrentamiento entre los hermanos Fernando I de León y Castilla y García III de Navarra, y se mencionan sus principales hitos: la falsa acusación contra la reina Sancha (hermana del difunto Bermudo III y esposa del rey castellano-leonés); la enfermedad del navarro y el posterior y fallido intento de captura del rey castellano por parte de García en esas penosas circunstancias; a continuación, la convalecencia del castellano, la visita de su hermano y, seguidamente, la prisión y fuga de García de su cautiverio en Cea. Luego, la Historia silense refiere la batalla del siguiente modo:

Garsias deinceps, acer et furibundus, cepit occasiones belli aperte querere, atque fraternum sanguinem sitiens, eiusdem fines, quos attingere poterat, hostiliter deuastare. Quibus auditis, Fernandus rex, collecto a finibus Gallecie inmensso exercitu, iniuriam regni vlcisci properat. Interim legatos ydoneos ad Garsiam regem mittit, quatinus dimissis finibus suis vteretur pace, neue cum eo mortiferis gladiis confligere presumeret; fratres enim erant, ideoque vnumquemque in regno suo deceret quiete viuere. Ad hoc tantorum militum multitudinem se sustinere non posse ei predicit. Porro Garsias rex, ferox et animosus, audita legatione, nuncios e castris, despecta fratris pietate, exire inperat, ac statim, subinferendo minas, eos cum sociis qui pugne subierint triumphato domino, more pecudum se rapere in patriam dicit. Confidebat namque Garsias in viribus suis, eo quod tune temporis, excepto regio inperio, pre omnibus militibus insignis miles habebatur. Siquidem in omni bello strenui milites et boni inperatoris oficia simul peragere assueuerat. Illexerat quoque sibi maximam turbam Maurorum, quos tumultus causa ad pugnam conscripserat. Igitur ab utroque dies et locus infelici pugne constituuntur.

Iam autem Garsyas in media valle de Athaporca posuerat castra, cum Fredinandi regis milites noctu desuper inminentem preoccupant collem. Qui nimirum milites ex cognatione Veremudi regis plerumque existentes, vbi voluntatem domini sui fratrem suum auidam viuum capiendi, potius quam extinctum, animaduertunt, vt credo instinctu Sancie regine, comunem sibi sanguinem vindicare singulariter anelabant. Mane itaque facto, cum primo Titan emergeretur undis, ordinatis acciebus, ingens clamor utrimque i attollitur, inimica pila eminus iaciuntur; mortiferis gladiis comunis res geritur. Cohors tandem fortissymorum militum, quos paulo $<$ ante $>$ tetigi, laxis habenis, desuper incursantes, per medias accies secando, omnem impetum, crispatis astis, in Garsiam regem inferunt, atque confossum, exanimem in terram de equo precipitant; in quo bello duo ex magnis militibus Garsie cum eo interfecti sunt. Sed et Mauri, qui pugne subierant, dum fugam arripere moliuntur, magna pars illorum captiuata est. Corpus vero Garsie regis in ecclesia beate Marie Nazarensis sepulture traditur, quam ipse a fundamento devote construxerat, atque argento et auro sericisque indumentis pulchre ornauerat

(Pérez de Urbel-González Ruiz-Zorrilla ed. I959: I86-I88). ${ }^{6}$

6. 'García desde entonces agrio y furioso empezó a buscar abiertamente ocasiones de guerra y, sediento de la sangre fraterna, a devastar hostilmente las fronteras del mismo a que podía llegar. Oído lo cual, el rey Fernando, juntado inmenso ejército desde los confines de Galicia, avanza a vengar la injuria del reino. Mientras tanto envía al rey García emisarios idóneos, a fin de que, dejados sus confines, gozase de paz y no presumiera de contender con él con espadas mortíferas, pues eran hermanos, y, por tanto, convendría vivir cada uno tranquilamente en su reino. Sobre esto le predice que no podría sostenerse contra tal multitud de soldados. Finalmente, el rey García, feroz y animoso, oída la embajada y despreciando la clemencia de su hermano, manda salir del campamento a los emisarios; y al punto, añadiendo amenazas, díceles que, vencido su señor, tanto a ellos como a los compañeros que sobrevivieren a la pelea arrastraría a su país como rebaños. Así confiaba García en sus fuerzas; porque en aquel tiempo, aparte el poder real, era tenido como militar insigne entre todos los militares: ciertamente, estaba hecho a desempeñar en toda guerra a la vez los oficios de militar valiente y de buen general. También había ligado a sí grandísima turba de moros, que por razón de alarma había reclutado para la batalla. Luego, por uno y otro se designan día y lugar para la desgraciada pelea. Mas ya García tenía puesto su campamento en medio del valle de Atapuerca, cuando de noche los militares del rey Fernando 
Las variantes más significativas de este relato se producirán recién con la obra de Rodrigo Jiménez de Rada. En efecto, De rebus Hispaniae (I243-I246) introduce ciertos matices en el texto que contribuyen fundamentalmente a atribuir las responsabilidades del conflicto al rey de Navarra y a caracterizarlo como un rey vengativo e iracundo, poco estimado por sus súbditos y soberbio, a la vez que ofrece un retrato benevolente de Fernando I. ${ }^{7}$

Al igual que en el texto de la Silense, y como es de esperar en el registro historiográfico, los hechos de la batalla también se vinculan en De rebus Hispaniae con acontecimientos previos que contribuyen a explicar las causas del enfrentamiento entre los hermanos. Pero hay otros elementos que se encuentran por vez primera en el texto del Toledano, especialmente en lo que hace a las circunstancias anteriores a la batalla y a la muerte del rey de Navarra. Este es el relato que don Rodrigo presenta sobre los hechos de Atapuerca incluidos en el capítulo X del Libro VI:

Cumque post transitum montis Auce consedisset in loco qui dicitur Ataporca, rex Fernandus ueniens ex aduerso per legatos pacem humiliter postulauit, ut contenti suis pace perpetua letarentur. Quod rex Garsias renuens, nuncios cominando grauia inhonorios a se misit. Cumque iam belli periculum inmineret, magnates et milites regni sui ad ipsum comuniter accesserunt humiliter supplicantes ut eis et ablata restitueret et leges patrias confirmaret. Cum enim precelleret strenuitate corporis et uirium magnitudine super omnes, adeo ut omnibus premineret, crudeli superbia grassabatur et possessiones militum infiscabat et iura patria inmutabat. Ipse autem solis uiribus autumans preualere, peticiones militum refutauit, ne uideretur annuere ex timore. Tunc duo milites, quorum bona proscripsertat, naturale debitum abnegantes se in aduersarium transtulerunt. Ad hec nutricius eius, qui eum ab infancia nutrierat, uir prudens et bonus, strenuus et fidelis, sinceris lacrimis consulebat ut et petitis annueret et sibi suorum animos complanaret. Rex uero animo induratus neutris satisfecit; tunc ille nutricius inquit: "Intelligo quod hodie uictus et inglorius morieris, set ego premoriar, ne te uideam morientem quem tanto studio enutriui”. Cumque se exercitus circumtectus et ad certamen undique properarent, ille nutricius depositis clipeo, galea et lorica pannis dumtaxat usualibus circumtectus, sola lancea et gladio comitatus, morti in prima acie se obiecit, ne alumpni et gentis excidii esset testis. Cumque mutuis cedibus hinc inde exercitus se impeterent, cepit preualere exercitus Castellanus, eo quod numero et potencia excedebat et rex Garsias suorum animos non habebat. Tunc quidam milites, qui fuerant ex familia Veremundi et noctu collem, qui Nauarrorum exercitui inminebat, clanculo occuparant, regis Garsie acies cum duobus militibus, qui ab eo recesserant, impetu irrumpentes ad regis aciem peruenerunt, et alter militum qui ab eo recesserat dicitur eum lancea perfodisse; ex quo ictu in terram cecidit rex Garsias et duo magnates, qui cum eu aderant, inibi ceciderunt. Cumque rex Fernandus fratre occiso et fugato exercitu de uictoria letaretur, pietatis non inmemor precepit suis ne fugientes lederent Christianos;

se apoderan, a la parte de arriba, de un collado próximo. Por cierto que estos militares, siendo en su mayoría de la parentela del rey Bermudo, cuando se percatan del vivo deseo de su señor de coger vivo a su hermano más bien que muerto, según creo por instigación de la reina Sancha, anhelaban singularmente vengar por sí la común sangre. Llegada así la mañana y como asomase el primer rayo de sol entre las ondas, ordenados los batallones, fuerte clamor se alza por ambas partes; arrójanse de lejos los enemigos dardos, y de cerca se manejan las espadas mortíferas; por fin, la cohorte de fortísimos militares de que hablé antes, echándose encima desde lo alto a rienda suelta y cortando a través de las filas lanza en ristre, convergen todo su ímpetu contra el rey García, a quien traspasado precipitan exánime del caballo en tierra; en cuyo combate dos de los grandes militares de García son matados con él. Aun los moros que habían entrado en batalla, mientras intentaban ponerse en fuga, son cautivados en gran parte. Mas el cuerpo del rey García se entrega a la sepultura en la iglesia de la bienaventurada María, en Nájera, que él había construido devotamente desde sus cimientos y adornado pulcramente con plata, oro y vestiduras de seda: año ıo54, día primero de diciembre’ (Gómez Moreno ed. I92I: CXVII-CXX).

7. Esta caracterización de los reyes, en germen en el texto de la Silense, ya había sido ensayada en el relato de la batalla que presenta la Chronica Naierensis, por cierto, primera crónica regia castellana que ofrece, en términos historiográficos, un punto de vista castellano (Martin 2009: §2) 
tamen Sarraceni qui aderant pro maiori parte captiuitate et gladio perierunt. Tunc rex Fernandus precepit corpus regis Garsie honorifice Anagarum deportari et in monasterio sancte Marie, quod ipse construxerat et donariis plurimis adornauerat, sepeliri

(Fernández Valverde ed. I987: I87-I89). ${ }^{8}$

Distintos motivos y secuencias se mantienen inalterados: el carácter sanguíneo de García III (ferox natura, rapidus in confiliis, ac lingua immodicus militum animos vehementer alienarat, lo describe don Rodrigo), el envío de mensajeros por parte de Fernando y su violenta y afrentosa expulsión por parte del rey navarro, el ataque al rey García desde una posición elevada (desuper incursantes, precisa la Silense); y son dos, asimismo, los nobles navarros que caen junto con el rey. Hay otro elemento en común que el texto del Toledano recorta parcialmente: la pertenencia del grupo de atacantes a las huestes de Bermudo III (derrotado y muerto diecisiete años antes en la batalla de Tamarón luego de la cual Fernando I se convirtió en rey de León en virtud de su enlace con Sancha, hermana del difunto rey). En efecto, la Historia silense da cuenta de este conflicto previo con mayor detalle, ya que presenta el regicidio como una venganza por parte de los súbditos de Bermudo III -ahora al servicio de Fernando I- quienes, al enterarse del deseo del rey de Castilla de capturar vivo a su hermano e instigados por la reina Sancha (vt credo instinctu Sancie regine), se apresuran a atacar mortalmente a García III. La primera persona que emplea la Silense (inexistente en el texto de Lucas de Tuy) también contrasta con el distanciamiento con que don Rodrigo presenta la acción: el ataque de los caballeros navarros se corrobora en la Silense internamente ("quos paulo <ante> tetigi”) mientras que el Toledano refiere de manera imprecisa a una fuente externa (dicitur). Son significativas las variantes que, precisamente al momento de presentar la motivación del ataque (o, probablemente, al buscar cierto orden y causalidad más propios de la narración que del caos de una batalla), asume la voz enunciativa en cada caso. ${ }^{9}$ Probablemente sea esta una forma de exculpar a

8. 'Cuando, después de pasar los montes de Oca, acampó en un lugar que se llama Atapuerca, el rey Fernando, que llegó por el otro lado, le envió embajadores solicitándole humildemente la paz, de forma que, contentándose cada uno con lo suyo, disfrutaran de eterna paz. Pero el rey García, sin acceder a ello, despidió a los embajadores de mala manera y con graves amenazas. Como la guerra ya era inminente, los nobles y los caballeros de su reino se le presentaron juntos a rogarle con humildad que les devolviera lo quitado y refrendara las leyes de la patria. Pero él, confiado en imponerse sólo con sus fuerzas, rechazó las peticiones de los caballeros para que no fuera a parecer que accedía por temor. Entonces, dos caballeros, cuyos bienes había confiscado, se pasaron al enemigo abjurando de su obligación natural. Ante esto, su ayo, que lo había criado desde niño y que era hombre prudente y bondadoso, valiente y leal, le aconsejaba con lágrimas no fingidas no sólo que accediera a las peticiones sino que se ganara los ánimos de los suyos. Pero el rey, obstinado en su resolución, no satisfizo a nadie. Entonces le dijo el ayo: "Veo que hoy vas a morir vencido y deshonrado, pero yo voy a morir antes para no ver morir a quien he criado con tanto cariño". Y en el momento en que los ejércitos se avistaron y se lanzaron a la lucha por todo el frente, el ayo, dejados el escudo, el casco y la coraza, vestido tan sólo con la ropa de diario, armado exclusivamente con la lanza y la espada, se lanzó a la muerte en primera línea para no ser testigo de la destrucción de su pupilo y de su gente. Una vez que ambos ejércitos se atacaron causándose mutuamente pérdidas, empezó a imponerse el ejército castellano porque era superior en número y capacidad ofensiva y porque el rey García no contaba con el favor de los suyos. Entonces, unos caballeros, que habían sido la escolta de Vermudo y que habían ocupado de noche y por sorpresa una colina desde la que se dominaba el ejército de los navarros, haciendo una descubierta contra las líneas del rey García junto a los dos caballeros que habían desertado, llegaron hasta la posición del rey García, y se cuenta que uno de los desertores lo atravesó con la lanza; a causa del golpe cayó a tierra el rey García junto con dos nobles que estaban con él’ (Fernández Valverde ed., I989: 231-232).

9. El texto del Chronicum mundi presenta del mismo modo la sucesión de acontecimientos y su motivación, aunque la visibilidad que adquiere el cronista en este pasaje de la Silense llama la atención. Probablemente se deba a la inconsistencia en la motivación para atacar a García con el propósito de asesinarlo. Armando Besga Marroquín señala en su estudio histórico sobre esta batalla: "No se entiende la aparición de Sancha en un relato tan corto si solo tiene el objetivo de explicar el origen del plan de Fernando i. Pero tampoco se entiende la actitud vengativa de Sancha, contraria 
Fernando I de la muerte de su hermano y de dirigir la atención del lector hacia la figura de la reina como posible instigadora.

Existen, además, diferencias que no alteran, en rigor, la armazón narrativa del episodio: si en la Silense son hombres de Fernando I quienes, en medio de la batalla, acometen y matan a García III (milites en sus tres ocurrencias), en el Toledano, en cambio, se trata de caballeros navarros que se incorporan a la historia antes del enfrentamiento reclamando ciertos bienes confiscados y abjurando luego del vasallaje al rey de Navarra ("naturale debitum abnegantes se in aduersarium transtulerunt”). En el relato de don Rodrigo, el rey García parece haber perdido todas las virtudes propias de un rey guerrero y temerario con las que lo describía la Historia silense ("pre omnibus militibus insignis miles habebatur. Siquidem in omni bello strenui militis et boni inperatoris oficia simul peragere assueuerat"), y haber exacerbado, al mismo tiempo, todos sus defectos morales convirtiéndose en poco menos que un déspota arbitrario y vengativo.

Ahora bien, hay dos secuencias completas ausentes tanto en la Historia silense como en el Chronicon mundi que se introducen en la versión de Jiménez de Rada y que sí modifican sustancialmente la estructura del relato: la petición a García III de restitución de ciertos bienes confiscados por parte de ciertos nobles y caballeros navarros ("magnates et milites regni sui") y su posterior deserción al bando navarro; y, en segundo lugar, el discurso profético y posterior sacrificio del ayo de García que prefiere morir antes de ver en desgracia a su señor. ${ }^{\text {Io }}$ Esta escena de alto patetismo participa, además, del tópico del buen vasallo que sirve a un señor injusto, lo que permitiría aducir una fuente oral para esta interpolación en particular." Este es el centro de nuestro interés y el objeto general de nuestro análisis: la emergencia, interpolación y desplazamiento de secuencias enteras en distintas versiones de un episodio muy conocido en el corpus cronístico latino y castellano.

Don Rodrigo incorpora en este punto a los caballeros navarros desnaturados de su rey que actúan junto con quienes habían formado parte de la escolta del rey Bermudo III. Hay en esta reelaboración una sutileza de notables consecuencias. Ambas crónicas mantienen una trama principal con sus causas y consecuencias a la que acompaña una trama secundaria, la muerte del rey García. Tanto el redactor de la Silense como el Toledano atribuyen a la envidia del de Navarra la causa del enfrentamiento entre ambos reinos. En cuanto a la muerte del rey, hay ciertas diferencias de peso. Por un lado, la Silense expresa (aunque de manera diferida) el deseo de Fernando de capturar vivo a su hermano ("vbi voluntatem domini sui fratrem suum auidam viuum capiendi, potius quam extinctum”), y reconoce únicamente en la venganza de los hombres de Bermudo III (ahora al servicio de Fernando I) la causa de la muerte de García en circunstancias propias de una batalla: luego de una lluvia de flechas y del combate cuerpo a cuerpo, una carga de caballería acomete al

a los deseos de su esposo, cuando era reina de León gracias a la muerte de su hermano; y tampoco se entiende el interés que podría tener el Silense por desprestigiar a Sancha, cuando la información no era necesaria para entender la noticia” (2009: 36).

IO. En su trabajo sobre el episodio de la mora Zaida, Alberto Montaner ha evaluado algunas de las modificaciones de la versión del Toledano como legendarias y hasta "fantasiosas", a pesar de que algunas de ellas tienen algún fundamento histórico (2005: 308-322). Cabe recordar, como señalamos al comienzo y veremos seguidamente, que la correspondencia o no entre los hechos y su representación no es el principal interés ni el enfoque de nuestro estudio.

II. Lindley Cintra ya había identificado el papel de los ayos como un motivo legendario propio de la epopeya castellana e incluye este episodio como ejemplo de este tópico (ed. I95I: CCCXCI, nota 207). Con menos elementos, Menéndez Pidal había atribuido ciertos datos referidos a la mora Zaida en el texto del Toledano a un cantar perdido (I929: I, 4O5-406). No es este, pues, el único caso en que el Toledano se inclinara por fuentes poco confiables y no asentadas en crónicas conocidas. En suma, tal y como observara Alberto Montaner a propósito de la leyenda de la mora Zaida, pareciera que "la historia oral se impone a la historiografía escrita, algo quizá menos usual de lo que cabría suponer" (2005: 314). 
rey que en el fragor del combate cae junto con dos de sus mejores guerreros. El Toledano presenta los hechos de manera algo diversa: es uno de los caballeros navarros quien da el golpe de gracia a quien fuera su rey (y no, como en la Silense, "Qui nimirum milites ex cognatione Veremudi regis plerumque existentes”). El episodio adquiere así mayor cohesión y consistencia narrativa: uno de los desertores (recordemos, "magnates et milites regni sui") que reclamara al rey la restitución de bienes propios y de las leyes del reino ("possessiones militus infiscabat; iura patria inmutabat") es quien atraviesa a García con su lanza. ${ }^{12} \mathrm{El}$ reclamo puntual de los caballeros pone en evidencia la costumbre del rey fundada en la fuerza y la soberbia (strenuitate corporis; uirium magnitudine; crudeli superbia) de confiscar tierras a los nobles y modificar las leyes del reino. Rodrigo expresa este hábito a partir del aspecto imperfectivo de los verbos que dan cuenta así de la prolongada duración en el tiempo de las injusticias de García sobre sus súbditos.

Esta interpolación en apariencia accesoria respecto de la Historia silense (y de la tradición previa a De rebus Hispaniae, incluido el Chronicon mundi) incorpora al relato de los hechos de Atapuerca un aspecto jurídico-político que se pone en primer plano: el Toledano hace referencia de manera algo elíptica a las reformas legislativas que la política eclesiástica de García había llevado a cabo en el territorio y que Fernando I rubricaría en el Concilio de Coyanza en I055 (Fita Colomé I895: I92-I93). Esta iniciativa jurídica (que constituyó una temprana recepción del derecho canónico en la región, véase García Gallo I950: 63ㅍ-632) implicó la restricción de ciertos usos y atribuciones de la nobleza a partir de una regulación que favoreció a las diócesis en el territorio de Navarra promoviendo y consolidando el proceso de concentración monástica iniciado en tiempos de Sancho el Mayor (Fortún Pérez de Ciriza 2005: 199-200). ${ }^{13}$ Este aspecto jurídico cobrará mayor relevancia

I2. Curiosamente, el Toledano duplica los pares de caballeros que intervienen en el final de la batalla de modo tal que dos caballeros abandonan y atacan al rey de Navarra y son otros dos los que caen junto con él, aunque solo al llegar al desenlace del episodio sabemos que fueron dos los desertores. Probablemente se trate de una contaminación derivada de la Silense (“duo ex magnis militibus Garsie cum eo interfecti sunt”) y, en ese caso, este agregado bien podría responder a una necesidad de simetría.

I3. Alfonso García Gallo ha precisado las modificaciones jurídicas y las consecuencias políticas de los estatutos de Coyanza. Curiosamente, al describir las implicancias políticas del Concilio, da mayor peso a una admonición éticomoral que a una prescripción de tipo jurídica: “el Concilio, a raíz de la batalla de Atapuerca, atento más que a lo jurídico a lo moral, que cae de lleno en la competencia de la Iglesia, ordena tanto a los maiores y a los inferiores como al propio rey que vuelvan a guardarse su fidelidad y sus derechos, como en el tiempo anterior a todas las discordias; que los pueblos no discutan la justicia del rey para fundamentar supuestos agravios” (I950: 362). Disociar la dimensión moral y política del imperium eclesiástico es cuando menos discutible. De hecho, el propio García Gallo reconoce, poco más adelante, la "innegable influencia política” del sínodo eclesiástico (ı95о: 363). En este sentido, señala Walter Ullman: “Según los principios papales de gobierno, cada cargo tenía adscriptas unas determinadas funciones, pero en relación con el todo, es decir, no eran ejercidas independientemente, sino en vinculación con todas las demás. Los oficios, tanto real como episcopal, existían con el mismo objeto de realizar los fines de la Iglesia, lo que constituía el importantísimo principio teológico del oficio: el contenido de cada oficio, sus funciones específicas, estaban íntimamente vinculadas y relacionadas con el objetivo o fin de la Iglesia entera" (г96г: 68); y más adelante: "La distinción entre las diversas categorías de actividades humanas -religiosas, morales, políticas, sociales, etc.- no tenía aún [en tiempos de Benedicto XII] vigencia en el campo social; solo contaba el todo, y el todo era indivisible” (г96r: 74). José María Lacarra, por su parte, describe este proceso histórico poniendo de relieve la limitación que las reformas de García ejercieron sobre las prerrogativas de las autoridades territoriales: “Ahora bien, si no hay noticia de la llegada de nuevos monjes reformadores, como en los días de Sancho el Mayor, el espíritu de la reforma había calado muy hondo en sus hijos, especialmente en el primogénito [García III], el cual, adelantándose al Concilio de Coyanza, reafirmó el ius episcopale sobre los dueños y patronos de las iglesias y monasterios” (I972: I, 244). En el marco de una interpretación general de los cartularios medievales, Carlos Sáez concluye que “la defensa de bienes, derechos y propiedades llevó a la confección de numerosos cartularios peninsulares. Varios concilios (León roiz, Coyanza Io55, entre otros muchos) habían legislado ya contra la rapiña de la nobleza y de la realeza contra los bienes de la iglesia con la intención de protegerlos" (2005: 6 ). 
en la versión de los hechos que presenta el manuscrito 43I y que analizaremos hacia el final de este trabajo: la fazaña desplaza el peso de lo historiográfico hacia lo jurídico imprimiendo de este modo al episodio el valor de antecedente. Debe considerarse la naturaleza ejemplar y, por lo tanto, didáctica y pragmática, de este tipo de textos, lo que lo convierte en una suerte de modelo válido de conducta a imitar o, al menos, en caso de referencia para decidir sobre sentencias futuras.

En este sentido, cabe destacar que con la caída de García III en el campo de batalla se representa al mismo tiempo en un plano simbólico una forma específica de administrar el poder y regular las relaciones sociales. En efecto, en los primeros tiempos de la dinastía Jimena de los reyes de Navarra, la forma de gobierno sigue el modelo isidoriano en el que la relación de fuerzas con el círculo de los barones es desproporcionadamente favorable al rey. Este equilibrio de poderes fue modificándose paulatinamente a partir de mediados del siglo XI en favor de los grandes del reino para dar lugar a "una concepción contractual de las relaciones entre el rey y los barones, en la que juegan un papel decisivo los bienes tenidos del monarca" y se regulan los vínculos entre el monarca y la alta aristocracia como un acuerdo entre iguales, cambio sustancial respecto del modelo isidoriano (Larrea 2005: I57-I58). Desde luego no fue este un acuerdo armonioso. La batalla de Atapuerca -seguida de la muerte en combate de García III- fue una de las múltiples aristas de esta contienda que tuvo otro capítulo destacado en el magnicidio, en el barranco de Peñalén, de Sancho IV, rey que fuera ungido precisamente en el campo de batalla de Atapuerca tras la muerte de su padre y que ocupara el trono de Pamplona hasta su muerte en Io 76 . Solo cuatro años antes, el propio Sancho IV de Navarra, en acuerdo con los barones, sienta las bases de un nuevo ordenamiento de las relaciones sociales y políticas intraestamentales: los honores, anteriormente concedidos por la sola voluntad del rey, se convierten, a partir de su reinado, en una retribución inalienable, con lo que se consolida la institución feudo-vasallática (Lacarra 1972: I, 26I-267; Larrea 2005: I58 y ss.). . ${ }^{14}$

La versión de los hechos de Atapuerca que presenta De rebus hispaniae incorpora la cuestión jurídica a la trama principal como un factor decisivo en la muerte de García III aunque todavía relegada a un motivo secundario. El texto del Toledano atribuye la causa principal del enfrentamiento al carácter envidioso e irascible del rey navarro. Complementariamente, el motivo del ayo refuerza el carácter arbitrario que regía las acciones de su señor y contribuye no poco a la consistencia narrativa del relato. Estas dos interpolaciones, ausentes en la tradición previa, contribuyen a fundamentar histórica y jurídicamente la perspectiva castellana del conflicto de modo tal que la reescritura de este episodio que Rodrigo lleva a cabo expresa los intereses territoriales de Castilla en esa región de la Rioja Alta. Asimismo, la reforma legislativa de Coyanza se representa en el texto como un mal hábito adquirido por el rey a lo largo del tiempo, consecuencia de sus deficiencias morales.

Será esta última versión la que se recupere en la historiografía romance y se consolide casi sin alteraciones en las crónicas castellanas de la segunda mitad del siglo XIII y a lo largo del XIV no sin antes atravesar un complejo proceso de traducción que conoció sus propias variantes. Ahora bien, ya en esta etapa previa pueden apreciarse con claridad dos tendencias propias del

I4. Este año signa la consolidación del linaje de los Haro en Castilla. El episodio de Peñalén contribuyó no poco al ascenso de esta casa dado que, con la dominación de Navarra, los señores de Vizcaya y Nájera, así como sus territorios se habían vuelto castellanos. Este linaje llegará a su apogeo luego de la alianza con Sancho IV contra su padre entre I284 y I288, año signado por el magnicidio de Alfaro, la sublevación y el posterior exilio de sus vasallos a partir del cual comienza el declive de los Haro (Baury 2OII). La estrategia de enfrentamiento con la monarquía desde el interior del reino que había consolidado a los Haro desde Peñalén en adelante y los había encumbrado a las zonas más altas del poder resultó contraproducente en la Castilla de fines del Doscientos. La narración del asesinato de Lope Díaz de Haro IV en la *Historia hasta 1288 dialogada constituye una de las múltiples tramas del discurso historiográfico de corte señorial del que aquí exponemos algunas características a propósito del episodio de Atapuerca.

Magnificat CLM 7, 2020, I-43. ISSN 2386-8295 
discurso historiográfico: la sedimentación (que tentativamente podríamos definir como el proceso de consolidación y fijación de un sentido recurrente, naturalizado y socialmente instituido y que implica, además y paradójicamente, el olvido de su propio origen o procedencia) y la reactivación (entendida como aquella instancia del discurso que revela el carácter contingente de los sentidos naturalizados y socialmente instituidos y que al mismo tiempo instaura un nuevo orden resignificando los sentidos preexistentes). Sedimentación y reactivación requieren de la tradición como campo fenoménico de acción y constituyen polos hacia los que puede inclinarse alternativamente un discurso historiográfico. Finalmente, ambos procesos permiten evaluar lo ideológico como la condición de posibilidad de cualquier nivel de significación en el discurso historiográfico. Un texto que tiende a la sedimentación afianza las relaciones sociales instituidas. Por otra parte, y en la medida en que un texto histórico reelabora un episodio modificando las formas elementales de ese relato (imágenes, agentes, atributos y acciones, etc.), la manifestación de sentidos no explícitos e imprevistos en una nueva representación de los hechos del pasado ofrece un punto de vista alternativo respecto de los sentidos socialmente instituidos y asimilados, reavivando de este modo un conflicto social en el presente. La reactivación hacia la que tiende este texto cuestiona, por lo tanto, las relaciones sociales instituidas a la vez que promueve y consolida otras, conmoviendo así los cimientos de la comunidad, aunque sin dejar de recrear un orden existente. Estos son precisamente la impronta política y el sesgo ideológico del texto que una perspectiva semiótica contribuye a poner de relieve.

El Toledano es el último eslabón de una extensa tradición, la historiografía latina hispánica que narra la batalla de Atapuerca. Los elementos que incorpora De rebus Hispaniae a este episodio (el motivo del ayo y el de los caballeros navarros que arremeten contra quien fuera su señor) constituyen elementos de reactivación respecto de la tradición previa de la que apenas hemos visitado los hitos más salientes. Estas modificaciones se enmarcan en un modelo de historia que responde a los intereses de la monarquía castellana de la primera mitad del siglo xIII y a su objetivo de centralización política. Sin embargo, a pesar de que la labor legislativa de Fernando III preparó el terreno para el proyecto jurídico-político alfonsí al impulsar notables innovaciones forales (como exportar el modelo del Fuero de Toledo a las tierras de la Andalucía recientemente conquistadas y colonizadas) y consolidó la potestad legislativa del monarca en un primer reconocimiento del monopolio de creación del derecho, el Rey Santo fue, desde el punto de vista estrictamente jurídico, un rey muy conservador de las estructuras jurídicas heredadas que canalizó todas las fuerzas sociales en la recuperación de territorios hispanos en poder del Islam (Martínez Diez I993: 252). En suma, el Toledano constituyó el fundamento para la tradición posterior, la cronística en lengua romance, en la que la materia de Atapuerca (ya motivo historiográfico) permaneció prácticamente inalterada hasta bien entrado el siglo XIv. Hacia allí se dirigirán ahora nuestros pasos.

\section{La batalla de Atapuerca en la historiografía castellana}

$\mathrm{T}$ al y como advirtiera oportunamente Diego Catalán, la obra del Toledano no solo continuó empleándose como fuente hacia fines del siglo XIII y bien entrada la siguiente centuria, sino que además fue romanceada en repetidas oportunidades por traductores independientes (I966). La relación de la batalla de Atapuerca se diseminó en la historiografía romance a partir de esas traducciones que acogieron en diversos cauces el texto latino. De la primera redacción de la Historia gothica de don Rodrigo se conservan dos traducciones, la Estoria de los godos y la (mal denominada, según Enrique Jerez) Versión completa de 1256 que Jerez caracteriza como "una iniciativa tardía, no anterior a los finales del siglo XIV y muy probablemente perteneciente ya al siglo XV" (2OO3: 
233-234). ${ }^{5}$ La segunda redacción de De rebus Hispaniae dio lugar al Toledano romanzado y a la Crónica o versión leonesa, una traducción tardía y muy abreviada del texto de don Rodrigo. El Toledano romanzado es la única versión que, en opinión de Enrique Jerez, podríamos denominar una traducción propiamente dicha de la obra de Jiménez de Rada (Jerez 2003: 235). Su versión de los hechos de Atapuerca, como era de esperar, es muy cercana al texto latino (Van Der Walt ed. I999: 327-328) mientras que la Estoria de los godos refiere una versión muy abreviada de los mismos acontecimientos (Ward ed. 2006: IO-I4).

De los hechos de Atapuerca que se recuperan en la historiografía castellana inmediatamente posterior solo conservamos dos crónicas: la reelaboración tardía del texto alfonsí denominada Versión crítica de la Estoria de España (1282-I284) y la Versión retóricamente amplificada de 1289 o Crónica sanchina (en adelante CS), proyecto historiográfico de Sancho IV bien diferenciado del de su padre, y cuyo texto fue editado por Menéndez Pidal como Primera crónica general (ed. 1955). El episodio se sitúa, por lo tanto, en una zona espinosa de la tradición manuscrita de la Estoria de España, al comienzo de la denominada Cuarta Parte dedicada a los primeros reyes castellanos y leoneses que abarca del capítulo 802 al 964 del texto editado por Menéndez Pidal. De esta sección solo contamos con representantes indirectos y tardíos de la Versión primitiva (el manuscrito $\mathrm{E}_{2}$, el manuscrito F, la Crónica de Castilla y la Crónica Ocampiana), y con el testimonio de la Versión crítica (el manuscrito Ss y los manuscritos de la Crónica de veinte reyes) (Campa 2003 y 2005: 47047I).

A pesar de que el enfrentamiento entre Fernando I y García III se encuentra en un punto problemático de la denominada cuarta parte de la Estoria de España, el relato de la batalla se mantiene relativamente estable y con mínimas variantes léxicas tanto en estas dos crónicas como en otros textos posteriores. Es cierto que no deben perderse de vista las especificidades de cada proyecto historiográfico que la crítica textual ha logrado identificar, labor que a lo largo de décadas y luego de los trabajos de Diego Catalán y sus continuadores ha marcado nuevos e ineludibles senderos. ${ }^{16}$ Pero, tal y como se desprende del cotejo de estas crónicas, parece indudable que el relato de la batalla de Atapuerca ha entrado a fines del siglo XIII en una fase casi definitiva de sedimentación. La Versión crítica de la Estoria de España incluye el episodio en el capítulo CCXXVI, mientras que Ramón Menéndez Pidal lo ubica en capítulo 804 de su edición. Transcribimos a continuación el fragmento que transmite la Versión retóricamente amplificada de 1289 o Crónica sanchina de la batalla sobre el que efectuaremos las comparaciones con las variantes

I5. La Estoria de los godos, fue datada muy tempranamente primero por José Gómez Pérez -quien la describiera como la primera traducción castellana que aparece en España en idioma vulgar (I962: 366) -, y luego por Enrique Jerez, quien sostiene que esta crónica se basó en la primera redacción de la obra del Toledano y ubicó su composición entre I252 o I253, "apenas cinco o seis años después de la muerte de don Rodrigo" (2003: 232). Aengus Ward, por su parte, la considera la "primera crónica castellana” (2002) y plantea objeciones consistentes para una datación temprana del texto llevando a ubicar su composición en los últimos doce años del reinado de Alfonso X a partir tanto de referencias externas como de elementos internos del texto (ed. 20o6: 9). Tal y como señalara Aengus Ward, si bien el texto de la Estoria de los godos sigue por momentos al pie de la letra el texto del Toledano se caracteriza por una estructura mucho más caótica que la de su modelo latino dada por cierta arbitrariedad en cuanto a la organización de la materia (2OO2: I85-I86). Pueden observarse, asimismo, una tendencia a la abreviación que hace de esta crónica "menos una traducción fiel de todo el contenido de De rebus Hispaniae que una versión abreviada en otra lengua del mismo” (2002: 187) y, paradójicamente, amplificaciones y agregados rayando la "novelización” "por parte de un redactor imaginativo resuelto a mantener la tensión dramática de su narración” (Ward 2002: 192). Estos rasgos estilísticos serán de especial interés al considerar la comparación con la fazaña del manuscrito 43I y, eventualmente, las características formales de textos como la *Historia menos atajante, la Historia hasta 1288 dialogada o la Crónica particular de San Fernando.

I6. Sería arduo meramente reseñar esta tarea editorial. Remito para ello al excelente panorama de la producción reciente en la materia que ofrece Georges Martin (20I2b). 
en otras crónicas:

804. El capitulo de como lidiaron el rey don Fernando et el rey don Garcia amos hermanos en Athapuerca, et murio y el rey don Garcia

Andados vii annos del regnado de este rey don Fernando -et fue esto en la era de mill et LX annos, et andaua otrossi estonces ell anno de la Encarnation del Sennor en mill et XXII, et el de Corrado emperador de Roma en III- en ell anno desta era de que dezimos el rey don Garcia de Nauarra, non auiendo al de fazer estonces et teniendo muy a coraçon de uengarse del rey don Fernando su hermano quel prisiera, ayunto muy grandes huestes de los suyos et de agenos, gascones et moros, et passo los montes dOca, et ueno a Athapuerca, que es a quatro leguas de Burgos, el finco y sus tiendas. Et el rey don Fernando su hermano luego que lo sopo, ayunto otrossi muy grand hueste et fue contra el, et enuiol adelante sus mandaderos muy omildosamientre a rogarle que ouiesse entrellos paz et amor como entre hermanos deuie ser, et quel saliesse de la tierra et non le fiziesse y mas mal de quanto le auie fecho, nin quisiesse que ouiesse entrellos muerte, ca eran amos hermanos, et que uisquiesse cada uno en paz en su regno, ca assaz auie en que. Mas el rey don Garcia non le precio nada tod esto, et enuio los mandaderos con grandes menazas et quitolos de si muy desondradamientre. Quando los ricos omnes et los caualleros de Nauarra uieron el periglo que podrie uenir en aquella batalla, uinieron todos al rey don Garcia et rogaronle muy omildosamientre que les tornasse lo que les tolliera et que les otorgasse sus fueros; ca el rey don Garcia, como era omne de grand coraçon et de gran fuerça que auie sobre todos los de la tierra, tomosse con soberuia los heredamientos de los caualleros, et con atreuimiento de su poder et de su fuerça non quiso otorgar a los caualleros lo quel demandauan, por que si lo fiziesse que semeiarie que lo fazie con miedo. Estonces dos caualleros a quien el rey tolliera lo suyo quitaronse del, negandol el natural derecho, et passaronse al rey don Fernando de Castiella. Ell ayo que criara al rey don Garcia de Nauarra era omne muy bueno et leal et sabidor et fiel et quando uio la cosa assi mal parada, conseio al rey don Garcia su sennor, llorando muy fuerte, que les otorgasse a aquellos caualleros lo quel demandasen et allanase los coraçones de sus uassallos; mas el rey seyendo de muy duro coraçon, non quiso a su ayo creer de conseio nin fazer lo quel conseiaua et rogaua. Et dixol ell ayo estonces: "bien entiendo que oy morras uençudo et affontado, por ende quiero yo morir antes porque non uea pesar de lo que crie con tan grand femencia et con tan grand guarda”. Et empos esto quando ell ayo alli nada pudo adobar, mouieronse las huestes los unos contra los otros, las azes paradas. Et aquel ayo del rey don Garcia salio a la plaça entre amas las huestes, et echo del cuello ell escudo et el capiello de fierro et la loriga fasta que se paro en pannos de lino et non mas, et su espada cinta et la lança en la mano, et fue ferir en los de la otra parte; et mataronle y luego en la primera az. Et assi quiso morir por non ueer la muerte de su rey nin el astragamiento de su yent. Et pues que las azes de amas las partes se fueron boluiendo et firiendo de cada cabo, la hueste del rey don Fernando como eran mas et mayor poder que los de la otra parte et mas las feridas que ellos dauan, fueronse uenciendo la hueste del rey don Garcia. Demas que el rey don Garcia non auie consigo los coraçones de los omnes, et esto era lo peyor. Estonces los caualleros que fueran de companna del rey Vermudo en uno con los dos caballeros que se quitaran del rey don Garçia porque los deseredara, prisieron un otero que era el mas alto lo | gar do estaua la hueste de los nauarros, et dalli derramaron descendiendo et firiendo por las azes muy de rezio fasta que llegaron a la az del rey don Garçia. Et uno daquellos dos caualleros que se partieran del rey que dio una lançada al rey et derribol a tierra, et murio y; et murieron y con el dos ricos omnes de los suyos. Pues que el rey don Garcia fue muerto et lo uieron los suyos, fue la hueste toda conturuiada, et començaron a foyr. Estonces el rey don Fernando pues que uio que el uencie, fue muy alegre, pero quel pesaua mucho de lo quel dixieron que el rey don Garcia su hermano era muerto; et dalli mouido, mando a los suyos que non fiziessen mas mal a los cristianos, et esto fue en grand poridad, et que los dexassen foyr et guarir. Mas a los moros que uinieran con el rey don Garcia mando que los matasen todos, et que muertos o catiuos non fuesen ende; et fue assi fecho, ca la mayor parte de todos fincaron y muertos o catiuos, que non 
escaparon sinon algunos pocos que se huuiaron meter entre los cristianos et fuxieron. Estonces otrossi el rey don Fernando mando leuar el cuerpo del rey don Garcia onrradamientre pora Naiara; et fue enterrado en un monesterio de santa Maria que fiziera el mismo y enrriqueciera de muchos donadios.

(Menéndez Pidal ed. 1955: I, 484, col. b, 1. 25-485, col. 2, 1. 36)

Introduce el relato una serie de cronologías y luego se señala la motivación principal de la acción: García III "non auiendo al de fazer estonces et teniendo muy a coraçon de uengarse del rey don Fernando su hermano quel prisiera" (484, col. I, 1. 36-39) reúne a sus tropas. Este motivo se retoma casi textualmente en la Versión crítica de la Estoria de España (en adelante VC) ${ }^{17}$, la Crónica de Castilla (en adelante CC) ${ }^{18}$ y la Crónica General de 1344 (en adelante Ci344) ${ }^{19}$ tanto en su versión castellana como portuguesa, ${ }^{20}$ y en todos estos textos se omite tanto la inacción de García III como la referencia a la prisión del rey de Navarra, de modo tal que la venganza por una deshonra (que no se explicita en el pasaje pero que se explica en los capítulos previos) queda como la causa principal del conflicto.

$\mathrm{Al}$ anoticiarse de la avanzada navarra, Fernando prepara su ejército y envía a su hermano "sus mandaderos muy omildosamientre a rogarle que ouiesse entrellos paz et amor como entre hermanos deuie ser" a los que García expulsa "con grandes menazas et quitolos de si muy desondradamientre" (484, col. I, 1. 46-48). Nuevamente, los textos mencionados describen la acción de manera casi idéntica a la Versión amplificada con alguna variante mínima (CC y Ci344 reemplazan "desondradamientre"; VC, desonrrada mente por "abiltadamente"). A continuación siguen a esta sección las dos secuencias introducidas por el Toledano: la petición de los ricos hombres de García y el sacrificio del ayo. En cuanto a la primera de ellas, únicamente VC y CS identifican como navarros a los caballeros que reclaman al rey sus posesiones. Todos los testimonios coinciden, en cambio, al incluir la petición de los nobles: que se les otorguen sus fueros y se les devuelva lo que se les había quitado (VC, CS, CC y Ci344) y los heredamientos (Ci344, manuscritos M y L) a lo que el rey responde "con gran soberbia de corazón” (VC, CS, CC y Ci344) y con "gran saña” (Ci344). Esta negativa provoca la reacción que se describe de manera casi idéntica: dos caballeros a los que el rey quitara lo suyo (VC, CS; que el rey tenía desheredados, CC, Cr344), se desnaturaron del rey (CC, Cr344; CS y VC, en cambio, "negandol el natural derecho") y abandonaron su corte para servir a Fernando de Castilla en vísperas de la batalla. La secuencia del ayo procedente del Toledano introduce, como vimos, un intenso patetismo (que se apoya en el consejo desoído por el rey, en la descripción del llanto y en las palabras del vasallo de García III), y se replica en todos los testimonios. A continuación, la batalla comienza a decidirse en favor del castellano debido al mayor

I7. Transcribimos en nuestras citas la edición de Mariano de la Campa (ed. 2009: 403-404). Para cada caso, además, hemos cotejado este texto con la Crónica de veinte reyes según la edición de Ruiz Asencio y Herrero Jiménez (ed. I99ı: I66-г67).

18. Referimos en cada cita de la Crónica de Castilla a la edición de Patricia Rochwert-Zuili (ed. 20IO: 7I-72).

I9. Para el caso de esta crónica, reproducimos la edición de Ingrid Videl (ed. 20I5: 574-575) que toma como base el manuscrito M. Hemos cotejado también el texto del manuscrito L (portugués) de esta crónica según la reconstrucción y transcripción de Sílvia Miranda (ed. 20I3: I38-I39). Llevamos a cabo el cotejo del material en este texto a sabiendas de que, tal y como señalara Cintra en la introducción a su edición, y desarrollara luego Catalán, la Crónica de 1344 sigue muy de cerca de la Crónica de Castilla (Fernández-Ordóñez I993: ı27).

20. Lindley Cintra demostró oportunamente que las ramas de manuscritos M, por un lado, y LP (portugueses) - UQ (castellanos), por otro, están separadas y no en relación de dependencia (ed. r95ı: LXXXVII). Ingrid Vindel incorpora al stemma el manuscrito E (\&-II-I de la Biblioteca de San Lorenzo del Escorial) a la familia castellana de la primera redacción de esta crónica (ed. 20I6: 20). 
poder de Fernando, pero también a que García no contaba con el corazón de los suyos, detalle que se transmite con variantes en cada uno de los testimonios bajo examen (CS: "Demas que el rey don Garcia non auie consigo los coraçones de los omnes, et esto era lo peyor"; VC: "Et demas el rrey don Garçia non avie consigo los coraçones de los suyos"; CC: "et demás que el rey don Garçía non auía consigo los coraçones de sus vassallos"; Ci344: "e demás que los del rey don García non avían coraçones para lo ayudar"). Seguidamente, se narra la muerte del rey de Navarra. En este caso, se involucra en la acción a "los caualleros que fueran companna del rey Vermudo en uno con los dos caballeros que se quitaran del rey don Garcia porque los deseredara" (CS; VC y CC con mínimas variantes). La Ci344, en cambio, se aleja del modelo de la CS al ofrecer una sucesión algo más azarosa de los acontecimientos, a la vez que introduce un mayor detalle en las heridas infligidas al rey:

E entonce los cavalleros de Navarra que se partieron del rey don García porque los deseredara se venieron para el rey de Castilla. E, andando por la batalla, tomaron los más altos lugares de la batalla, en tal guissa que llegaron dond'el don García de Navarra estaba e derribáronlo del caballo. E tantos le dieron golpes con los cuentos de las lanças fasta que lo mataron. E morieron hý con él dos ricos ombres. Es después que fue muerto el rey don García e su hueste desbaratada fue el rey don Fernando mucho pagado -empero que fue movido con gran piadad-. E mandó a los suyos que no fiziesen mal a los christianos, mas que se vengasen en los moros que hý andavan.

(Videl ed. 2015: 575)

El desenlace es el mismo en todos los textos, y (con mayor o menor detalle) se cierran los correspondientes capítulos con el "grande duelo" de Fernando I sobre el cuerpo de su hermano, el envío con honores del cuerpo a Navarra y su entierro final en el monasterio de Santa María de Nájera. Asimismo, se establecen las sucesiones y límites de los reinos según las convenciones propias del género cronístico.

Como adelanté más arriba, las secuencias básicas en las que se descompone la acción permanecen prácticamente inalteradas en todas las versiones castellanas y pueden detallarse del siguiente modo:

I. Ataque del rey de Navarra motivado por la envidia.

2. Reacción del rey de Castilla y envío de mensajeros.

3. Maltrato y amenazas a los mensajeros por parte de García III.

4. Reacción y demanda de fueros y tierras por parte de ricos hombres y caballeros navarros al rey.

5 . Airada negativa del rey.

6. Episodio del ayo.

7. Combate.

8. Muerte del rey.

9. Entierro con honores de García III.

En todos los casos, los hechos de Atapuerca se enlazan, como es habitual, con la historia del reino de Castilla, así como con la de los reinos vecinos, especialmente el de Navarra. La división en capítulos consolida la relación entre la estructura del relato historiográfico (su forma) y los sucesos del reino (su contenido) lo que tiene su correlato en la atención que se presta en todas las versiones 
a las exequias que Fernando I ofrece al cuerpo del rey de Navarra: su traslado al monasterio de Santa María de Nájera hasta su descanso final, oportunidad que los cronistas aprovechan siempre para recordar la obra piadosa de García III. De este modo, sus acciones negativas se ven compensadas por la devoción religiosa, de modo tal que la institución monárquica no se ve de ningún modo degradada por la conducta de un rey arbitrario.

En definitiva, los diversos textos historiográficos del Doscientos y del Trescientos que dan cuenta de la batalla de Atapuerca mantienen relativamente estable el esquema narrativo básico desde los primeros moldes latinos hasta su consolidación en la historiografía castellana. ${ }^{21}$ Los cambios más significativos en la transmisión de esta materia se dieron a partir de las redacciones latinas de la obra del Toledano que en la primera mitad del siglo XII lograron afianzar la legitimidad de Castilla como reino hegemónico y unificador de los territorios cristianos al norte de la península. Las crónicas castellanas que le siguieron transmitieron fielmente este relato.

\section{De la crónica a la fazaña. Una historia singularmente amplificada}

C lada perspectiva historiográfica ofrece un relato coherente de los sucesos de uno o varios reinados en función de la ideología historiográfica de cada texto. En efecto, la ideología historiográfica alfonsí proponía una continuidad entre los godos y los reyes astur-leoneses (Catalán I997: 465; Fernández-Ordóñez 1992: 20 n. i9) en virtud de la peculiar "perspectiva universal” (Funes 1997: 46) que se configuró en este modelo historiográfico "tomando como base un escenario permanente donde actúan pueblos diversos" (Catalán r992: 3I). El modelo de la "crónica", a diferencia del de la "estoria" del Rey Sabio, organizará luego los acontecimientos históricos desde la perspectiva de la narración parcial de un reinado o un grupo de reinados, modelo que se consolidaría hacia mediados del trescientos con la obra de Fernán Sánchez de Valladolid y alcanzaría su punto culminante con las crónicas de Pero López de Ayala (Gómez Redondo 200oa; 20oob). Por otro lado, parte de los textos a los que aquí hicimos referencia se encuentran en rigor a mitad de camino entre estos dos grandes modelos al apartarse, en mayor o menor medida, de los patrones de escritura de las estorias alfonsíes. Tal es el caso, por ejemplo, de la Crónica de veinte reyes y la Crónica de Castilla, que se alejan del modelo del Rey Sabio al recortar "en el tiempo y en el espacio su propio objeto histórico: la historia exclusiva de Castilla, sea desde sus orígenes como condado (CVR), sea desde sus orígenes como reino (CC)" valiéndose para ello no solo de los borradores y cuadernos de trabajo del scriptorium alfonsí, sino también de relatos originales referidos a la historia reciente de Castilla (Funes 2003). Para el caso del episodio que nos ocupa, esta distinción es perceptible únicamente en las variantes mínimas que el relato manifiesta en cada actualización. En este sentido, las implicaciones profundas de cada una de estas versiones se expresan en variaciones léxicas, sintácticas, semánticas, narrativas y en otros niveles mínimos del discurso; en aspectos estructurales como la segmentación del gran relato de la historia en libros, secciones o capítulos; también en la historia de los testimonios de cada monumento historiográfico, así como en el devenir de los valores políticos, ideológicos y culturales, aspectos

2I. Llamativamente, la Crónica abreviada de don Juan Manuel (compuesta entre I320 y I325, según Diego Catalán I977) omite el enfrentamiento entre Fernando I y García III en Atapuerca, aunque sí registra, en el segundo capítulo del Libro III, "quel rey don Garcia de Navarra tomaua quanto podia aver del rey don Fernando, su hermano, por enbidia que avie del” (Blecua 1983: 742) y repone seguidamente el modo en que García, estando enfermo, intentó apresar a Fernando, así como la posterior convalecencia del rey de Castilla y la visita de su hermano "por le fazer emienda delo quel quisiera fazer” (Blecua ed. 1983: 742) seguida del encarcelamiento del rey de Navarra en Cea. 
ambos que permiten delinear el marco de producción y recepción de cada texto. Como señalé más arriba, Georges Martin (1992), Marta Lacomba (2009) y Alberto Montaner (2005), han llevado a cabo y de diversas maneras análisis comparativos sobre el material historiográfico. Los episodios seleccionados en cada caso constituyen calas en el gran relato de la crónica medieval que permiten observar, sobre una base común, patrones generales de escritura en cada momento histórico.

Al centrarnos en el último caso de estudio, los contrastes entre las versiones historiográficas y el testimonio que transmite el manuscrito 43I de la Biblioteca Nacional de España serán cuando menos sorprendentes. Los cambios que allí encontramos no son únicamente variantes de una materia historiográfica tradicional; constituyen además rupturas en distintos niveles del discurso que requieren una mirada atenta y detenida sobre la emergencia de una escritura que creemos singular. No se tratará, entonces, de detallar las especificidades de cada enunciación historiográfica del episodio de la batalla de Atapuerca (labor, desde luego, necesaria, que aquí hemos apenas reseñado y que bien podría desarrollarse en el futuro), sino de identificar y describir, en este corpus previo, los protocolos básicos de escritura en prosa en la Baja Edad Media castellana con miras a establecer las particularidades formales de la versión incluida en el manuscrito 43I. Los rasgos de esta escritura permiten sostener, asimismo, la existencia hacia mediados del Trescientos de un foco de producción cronística ajeno a la corte regia, en el que la aristocracia habría impulsado la redacción y fijación por escrito de su propia versión de la historia y del derecho. Esta versión abre la colección de fazañas que se encuentra al final del códice. Los textos allí reunidos revelan la voluntad de sostener un orden social y político tradicional según el cual la relación entre el rey y los nobles se concibe acorde a los términos de la mentalidad señorial: equilibrio del poder, mutuo apoyo, plena vigencia del lazo personal entre el rey -primus inter pares antes que soberano ${ }^{22}-$ y los grandes señores de la tierra cuyos fundamentos políticos, institucionales y jurídicos (el sistema de behetrías, la relación feudovasallática y la facultad de crear derecho dentro de sus dominios, entre otros) habían entrado, ya a mediados del siglo XIV, en una etapa de decadencia irreversible.

La colección final data de principios del reinado de Pedro I, no antes de I353, fecha en que Vasco Fernández fue nombrado arzobispo de Toledo tal y como se destaca en la fazaña I5. Se trata en general de normas relativas a derecho de hidalgos: rieptos, desafíos, aleves y traiciones, adquisición y pérdida de la hidalguía, muertes y arrendamientos de impuestos por hidalgos. Estos textos presentan la acción de una manera muy sintética anticipando su desenlace, $\mathrm{o}$ al menos ubicando al lector (o al público, si consideramos una difusión oral previa a la puesta por escrito de estos breves relatos) en un momento histórico preciso, presumiblemente bien conocido, ya que se atribuyen a distintos reyes: la primera, que es la que nos ocupa en esta oportunidad, a Fernando I; cuatro a Alfonso X; dos a su hijo Sancho IV y una a Fernando IV; el resto, unas doce fazañas, a Alfonso XI.

La representación del pasado, por su parte, lejos está de ser desapasionada; muy por el contrario, está cargada de idealizaciones, proyecciones y afecciones sobre los acontecimientos narrados. El texto que nos ocupa está precedido por una suerte de prólogo que transmite una versión de la

22. Para el caso específico del reino de Navarra en el siglo XI, Juan José Larrea ha descrito esta relación del siguiente modo: "el objetivo de los barones no podía ser prescindir del rey. Siendo éste la clave de arco de una organización política y administrativa sólida y extendida por todo el reino, se trataba de limitar su autoridad judicial y remplazar la antigua relación de servicio por una nueva de carácter contractual, feudal. El rey debía ser en el mejor de los casos un camarada, y en el peor un rehén” (2005: I57). Desde una perspectiva jurídico-política de mayor alcance, José Manuel Pérez-Prendes y Muñoz de Arraco considera que a lo largo de la Baja Edad Media leonesa, castellana y aragonesa, "se desenvolvió una guerra civil sorda y episódica a veces (pero permanente siempre, aunque fuese en latencia) entre rey y poderosos, en defensa de sus dos proyectos contrapuestos de arquitectura política"; entre "un modelo de Estado dual basado en la relación general y directa entre rey y súbditos, por otro tripartito inspirado en la articulación rey-poderes subordinados-súbditos, es decir, lo que algunos llamamos 'Estado feudal', o mejor 'feudalizado"” (I989: 479). 
Leyenda de los Jueces de Castilla tan singular como esta de Atapuerca y le sigue una fazaña sobre desafiamientos de tiempos de Alfonso X (más precisamente hacia I254-I255). No se manifiesta, al menos en apariencia, ninguna relación explícita entre estos tres textos breves y autónomos de lo que podría denominarse "historiografía jurídica" ${ }^{23}$ Los hechos de Atapuerca se presentan en esta versión del siguiente modo:

I. Título de una fazaña del tiempo del rey don Ferrando de Castiella.

El rey don Ferrando de Castiella lidió con el rey don Garçía de Navarra su hermano en Atapuer[c]a, çerca de Burgos, et murió el rey don Garçía. Et una noche ante de la pellea dos cavalleros navarros, que al uno dezían Martín Peres et al otro Día Perez de Barzina, teníalos el rey desseredados. Et vinieron al rey et pidiéronle merçed que les dexasse su heredat. Et él non quiso. Et dispidiéronse d'él et desnaturáronse et otro día en la mañana, entrante la pelea, pusiéronse en çima de un ribero con los que pudieron aver et quando los reyes vinieron a la pelea dexáronse derribar del cabesço en que estavan et firieron en el tropel del rey de Navarra et derribáronle del cavallo et matáronle et inchiéronle la garganta de tierra et dixiéronle: "La tierra tomastes, et fártate de tierra".

Et fasta aquí dize la fazaña de los fijos dalgo et dizen los privados de los reyes, que an de guardar su razón, que verdat es que asý pasó. Mas otro día, que estos cavalleros vinieron al rey don Ferrando et dixieron: "Señor, fazednos merçed por el serviçio que vos fiziemos ayeri". Et él dixo: "Plázeme, mas nunca veades rey". Et estas palavras que fueron sentençia.

(Soler Bistué ed. 20I6: 26I)

Las diferencias respecto de los testimonios descritos más arriba son notables. ${ }^{24}$ Con respecto al género, en principio, el pasaje del discurso historiográfico propiamente dicho al de la fazaña jurídica tiene implicaciones muy concretas en la configuración del relato. Como señalamos al comienzo de este estudio, la fazaña se caracteriza por su brevedad y concisión narrativa a la vez que podría haber constituido un antecedente, es decir, haber sentado un principio jurídico rector para situaciones o casos análogos a los que presentaba. En este sentido, la fazaña guarda cierta relación con la impronta didáctica y ejemplarizante de la historiografía medieval, aunque con una diferencia de peso: si, efectivamente, la historia puede proporcionar modelos de conducta (al decir de Pero López de Ayala, "por que los que despues dellos viniessen tomen lo mejor, e mayor esfuerço de fazer bien: e de se guardar de fazer mal" [Orduna ed. 1994: LXXXVII]), el texto jurídico por su parte ofrece una pauta ético-moral y un marco regulatorio de acción con pretendida fuerza de ley..

23. En base tanto a aspectos materiales como a patrones internos de configuración del discurso, he señalado que "el códice pudo haber sido compuesto, en virtud de los intereses nobiliarios que allí encuentran fundamento (como la prerrogativa de crear derecho, entre otros), en algún centro de producción ajeno a la corte regia de Pedro I, un scriptorium nobiliario ligado a alguna de las grandes familias de la aristocracia castellana” (Soler Bistué ed. 2OI6: LXXXII). Para el desarrollo de esta interpretación de conjunto de los textos y colecciones jurídicas, incluidos en el manuscrito 43I, ver Soler Bistué ed. 20I6: XCIII-XCVII.

24. Para un estudio en detalle del texto de esta fazaña véanse Soler Bistué 2oro y ed. 2or6: CXIX-CXII.

25. Esta pretensión se fundaba en que el derecho territorial de cuño señorial, en el momento de composición de este códice, ya había perdido toda eficacia y validez, y entrado en una etapa de decadencia irreversible que se extendería sin embargo hasta comienzos del siglo XIX. El Ordenamiento de Alcalá de I348 había incorporado las Partidas al sistema de prelación de fuentes y, en consecuencia, la aplicación del texto alfonsí quedó no en manos de los “caballeros sabidores o foreros" sino en las de los juristas formados en el derecho común y "aunque la doctrina de los juristas del 'ius commune” no era aplicable directamente en los tribunales, el rey reconoce su autoridad. Esta actitud del monarca fue posiblemente la que determinó que los juristas, formados en el 'ius commune', muy pronto invocaran, en contra de lo dispuesto en el orden de prelación de fuentes, los textos y las opiniones de los tratadistas del “ius commune”" (Sánchez Arcilla Bernal I994: I3; la cursiva no figura en el original). 


\section{I Estructura narrativa de la fazaña}

Este tipo textual se caracteriza formalmente por una autonomía en cuanto a su contexto inmediato: el episodio de la batalla se presenta en este caso como un fragmento historiográfico aislado sin conexión con otros sucesos anteriores o posteriores de la historia del reino. Asimismo, la autonomía incide en la estructura narrativa de este relato, que se ha visto notablemente modificada: se han suprimido secuencias enteras, otras se han alterado, y el conflicto principal (o núcleo del relato) se ha visto desplazado para centrarse, más que en las vicisitudes históricas de los reinos involucrados en el conflicto, en dos hechos puntuales: la pérdida de heredades de algunos nobles y la muerte del rey García III de Navarra en el campo de batalla. Al prescindir no solo de los paratextos propios del género historiográfico (prólogo, atribución de autoría, división capitular, etc.) y de los antecedentes inmediatos de la acción (que la motivan a la vez que incorporan el episodio al gran relato de la Historia), sino también de varias de las secuencias descritas más arriba y que se habían mantenido inalteradas desde la redacción del Toledano, las acciones realizadas por los caballeros navarros ganan en autonomía y cobran por lo tanto un mayor protagonismo.

En efecto, la versión del manuscrito 43I se desprende de las secuencias I ("ataque del rey de Navarra motivado por la envidia"), 2 ("reacción del rey de Castilla y envío de mensajeros"), 3 ("maltrato y amenazas a los mensajeros por parte de García III"), 6 (“episodio del ayo") y 9 ("entierro con honores de García III"); y todo gira en torno a las secuencias 4 ("pedido de heredades por parte de los nobles") y 8 ("muerte del rey"), en tanto que las secuencias 5 ("negativa del rey") y 7 ("combate") se han visto reducidas a su mínima expresión y relegadas, por lo tanto, a un segundo plano. Esta versión introduce los hechos de los que va a tratar con una muy sucinta descripción del conflicto, que se reduce a la mención de un conflicto armado en Atapuerca entre Fernando I y García III, y de que este murió en allí. No se expone en esta versión la motivación del enfrentamiento; los reyes no tienen tratativas previas a la batalla, ni hay registro alguno del entierro del rey de Navarra; tampoco se mencionan los sucesores a la corona ni las consecuencias en la expansión del reino de Castilla, de modo tal que el episodio pareciera dar comienzo in medias res. Por otra parte, los reinados -en tanto que unidades geopolíticas- tampoco alcanzan la trascendencia que tenían en las crónicas, ya que no se trata del dominio de un territorio o del gobierno y sucesión de un reino, sino de la restitución de heredades a un grupo de caballeros navarros. En suma, los reyes (así como su corte, sus consejeros, sus decisiones, sus herederos y posesiones, en definitiva, su historia) y los grandes linajes y genealogías han perdido aquí todo protagonismo y toda relevancia histórica.

La primera consecuencia de este cambio de género es que el fragmentarismo y la autonomía que caracterizan a estos textos, y que la fazaña expresa paradigmáticamente, dominan la perspectiva historiográfica. La escritura descoyuntada de la historia -según la acertada expresión que utiliza Manuel Hijano Villegas para referirse a la Estoria del fecho de los godos (2000) - privilegia determinadas secuencias a expensas incluso de la cohesión y la coherencia internas del relato, destacando así al sector nobiliario del fondo común de la historia de los reinos hispanocristianos. Nos detendremos a continuación en un análisis del texto de la fazaña.

\subsection{Recursos y procedimientos}

En cuanto a los procedimientos formales de escritura de esta versión de los hechos de Atapuerca, pueden observarse diversas modificaciones en la construcción del relato: por un lado, se incluyen ciertos detalles y elementos que no encontramos en versiones anteriores o posteriores (nombres propios, un peculiar uso del discurso directo, ciertas acciones de los personajes) al tiempo que la 
acción propiamente dicha se recorta contra un fondo histórico reducido a su mínima expresión.

Como vimos, la síntesis se lleva a cabo a expensas de un cambio en el centro de interés del relato, ya que tanto la historia de los reinos de Castilla y Navarra como la de los reinados de uno y otro rey han sido desplazadas. En esta versión tardía, el núcleo de la historia es la muerte del rey García III de Navarra, y toda la acción recae, en definitiva, sobre los dos nobles navarros que emboscan y asesinan al rey y reclaman a ambos monarcas (en diversas oportunidades y con distinta suerte) la restitución de sus heredades. Si prestamos atención, por ejemplo, a los verbos conjugados que emplea la voz narrativa, la abrumadora mayoría de estas acciones (quince ocurrencias, siempre en tercera persona del plural) corresponde a los caballeros navarros, en tanto que solo siete son realizadas por los reyes: cuatro por el rey García (murió, teníalos desseredados, dexasse, quiso), dos por Fernando de Castilla (lidió, dixo), y solo una forma verbal es llevada a cabo por ambos reyes en conjunto (vinieron).

Por otra parte, el discurso directo interviene de manera muy distinta a como lo hiciera en $D e$ rebus Hispaniae, la Versión crítica de la Estoria de España, la Crónica sanchina o sus versiones posteriores. En todos estos casos, el discurso directo se localiza al comienzo del episodio en un momento previo a la batalla y de evaluación de los acontecimientos narrados, y se concentra en un solo personaje: el ayo del rey -“uir prudens et bonus, strenuus et fidelis”, según el Toledano; "un omne muy bueno et leal et sabidor et fiel”, traduce el texto de la Versión crítica, explicitando un sistema de valores (strenuitas, fidelitas, benignitas), y reafirmando al mismo tiempo la impronta jurídica del relato-. Su voz, acompañada de súplicas y llanto ("sinceris lacrimis consulebat"; "llorando muy fuerte"), se refiere primero de manera indirecta al dar el consejo; luego, se destaca y contrasta con el tono neutro del narrador, y se propone incidir en la decisión del rey con el propósito de que García III reconsidere el pedido de los caballeros (que, por cierto, ya habían rogado al rey "mucho homilldosamente que les diera lo suyo"; "humiliter supplicantes"): "bien entiendo que oy morras uençudo et affontado, por ende quiero yo morir antes porque non uea pesar de lo que crie con tan grand femencia et con tan grand guarda" ("Intelligo quod hodie uictus et inglorius morieris, set ego premoriar, ne te uideam morientem quem tanto studio enutriui”, en la versión del Toledano).

Tras la negativa de García III al pedido del ayo (que constituye en rigor una insistencia, dado que se expresa aquí por segunda vez la demanda de los caballeros), el texto pone de relieve tanto el carácter iracundo y obstinado del rey de Navarra como la arbitrariedad de sus acciones. ${ }^{26}$ Con estas palabras, el ayo cumple con el deber de aconsejar y mantenerse fiel a su señor, lo que lo lleva a enfrentarse primero a su rey y luego, casi desarmado, al enemigo y a una muerte segura. El ayo expresa así un ethos nobiliario que se erige en modelo de conducta confiriendo al episodio una impronta decididamente ejemplar que despierta admiración y compasión en los destinatarios del relato. A la vez que se evalúa negativamente la conducta del rey desde ese parámetro moral, se exalta en esta secuencia uno de los valores fundamentales del pacto feudo-vasallático que vinculaba y obligaba a ambas partes por igual: la lealtad al señor bajo cualquier circunstancia ("iQué buen vasallo, si hubiese buen señor!"). La noción moral de "bondad" que se infiere de la conducta del ayo tiene indudablemente una proyección política y una función ejemplar. Su muerte prefigura, además, la caída del reinado de García III: extraviado el sentido moral del monarca, su gobierno solo puede encontrar un fin aciago (aunque no el reino, del que, tal y como se consigna en algunas crónicas de este corpus, Sancho de Peñalén tomará posesión seguidamente).

26. La conducta de García III cuadra en los principales efectos de la tiranía en el reino que Egidio el Romano describe en su De regimine principum: perjudica el bien común, fomenta la obediencia ciega al tirano por el temor que inspira, reúne todo el poder en un mal príncipe, tiende a desposeer a los súbditos de sus bienes. Sin embargo, si el origen del rey era legítimo y no por la fuerza, la resistencia no podía de ningún modo justificarse (Nieto Soria 2OI7: 47). 
En un segundo plano queda, en cambio, la conducta de los caballeros navarros: su acción no se enaltece ni se condena en virtud del respaldo jurídico que la sostiene. García III de Navarra es el protagonista de este episodio historiográfico que narra su caída en desgracia. El rey va encontrándose gradualmente con diversos oponentes y formas de resistencia: primero su hermano, el rey Fernando I de Castilla y León; luego, los mensajeros que este le envía; en tercer lugar, los ricos omnes y caballeros de Navarra; y, finalmente, el ayo. Todos estos personajes manifiestan distintos aspectos de disenso así como de cercanía respecto del rey. La respuesta de García III es en cada caso reprochable: se muestra envidioso con su hermano (y par, dado que ambos son reyes), violento con los mensajeros, arbitrario e injusto con sus vasallos y soberbio e indiferente a los consejos del ayo fiel. ${ }^{27}$ Finalmente, siguiendo en este punto las versiones alfonsí (según la reelaboración que lleva a cabo la Versión Crítica de I282-I284) y sanchina (de I289) del episodio, el séquito del rey Bermudo y los dos caballeros navarros desnaturados acometen al rey en la batalla y uno de estos dos le da muerte. Entre la arbitrariedad del rey y la abnegación obligada del ayo, los caballeros ocupan en estas crónicas del Doscientos un lugar y un punto de vista en el que se configura un modelo de lector: el relato promueve cierta empatía hacia los nobles del reino, y el destinatario puede así proyectarse y contemplar el decurso de la historia desde una posición distante pero no del todo neutral, dado que algunos de estos caballeros tomarán posición en el relato y se enfrentarán a su rey en el campo de Atapuerca.

En suma, del episodio de Atapuerca incluido en el corpus historiográfico castellano se infiere un principio ético-moral que conmemora y actualiza el pacto feudo-vasallático: el vasallo debe siempre aconsejar al rey del mejor modo posible y acompañar a su señor sea cual fuere su decisión final; el señor, por su parte, debe atender a la justicia y los intereses del reino; a las obligaciones del consilium y el auxilium del vasallo, el señor debía retribuir con la concesión o confirmación de tierras o heredades; la fidelitas ligaba orgánicamente ambas partes.

En la fazaña, a diferencia de lo que sucede en las crónicas, el discurso directo se distribuye en el texto, y se ubica no en el centro, sino en el cierre de dos secciones claramente diferenciadas. La primera de ellas se aboca casi exclusivamente a la batalla y la muerte del rey, y se cierra con las palabras de los nobles sobre el cadáver de García III: “¡La tierra tomastes, et fártate de tierra!”. La segunda consiste en una suerte de coda o colofón, un sucinto diálogo entre el rey Fernando I de Castilla y los caballeros que dieron muerte a García III, que constituye y se superpone con el cierre formular de la fazaña al incorporar la sentencia del rey: “Plázeme, mas nunca veades rey”. Et estas palavras que fueron sentencia”.

Seguidamente, prestaremos oído a las voces del texto, en especial a las palabras de los caballeros navarros.

\section{$5 \cdot 3$ La muerte del rey}

En cuanto a la primera de estas secciones, el discurso directo refuerza, en principio, el detalle en la descripción de la muerte de García desde una focalización singular. El discurso directo es un recurso técnico que consiste en la recreación ficcional del acto comunicativo y genera en el lector

27. La construcción, ya presente en el Toledano, es magistral. Nótese la gradación y la simetría de esta configuración de personajes: el rey de Castilla (objeto de envidia) es representado por sus mensajeros (objeto de violencia), mientras que el ayo (objeto de soberbia) representa a los nobles del reino de Navarra (objeto de injusticia). El rey de Navarra (que es sujeto de envidia, violencia, soberbia e injusticia) pierde, debido a sus acciones arbitrarias, autoridad y legitimidad; es decir, pierde capacidad de representación política (en el plano del enunciado) y semiótica (en el plano de la enunciación). 
un efecto de acercamiento a los hechos narrados. Por lo tanto, si en la versión del Toledano el lector asiste a una sesión de cortes en las que se dirime una cuestión jurídica que tendrá secuelas en el enfrentamiento, en la fazaña, en cambio, las palabras proferidas por uno de los caballeros navarros nos acercan a la acción propiamente dicha, nos ubican allí, en medio del campo de batalla, proporcionándonos, además, aspectos novedosos acerca de este episodio. En este sentido, la sucesión de acciones que llevan a la muerte de García (derribáronle, matáronle, inchiéronle, dixiéronle) imprimen un dinamismo al acontecimiento central en virtud de otras acciones elididas aunque presupuestas (apearse del caballo, acercarse al cuerpo del rey, tomar tierra del suelo, etc.). Dos de estas cuatro acciones ya se encontraban en la tradición anterior, tanto latina ("recesserat dicitur eum lancea perfodisse; ex quo ictu in terram cecidit rex Garsias") como castellana (dio una lançada, derribó); las otras dos, especialmente significativas para nuestro análisis, son incorporaciones propias de la fazaña: el ultraje del cuerpo exánime del rey García y, en segundo lugar, el parlamento final que adquiere la forma de una sentencia y da sentido a todo el episodio. ${ }^{28}$

Hemos señalado que en todas las versiones anteriores la muerte del rey se representa como una vicisitud propia del combate cuerpo a cuerpo. ${ }^{29} \mathrm{~A}$ esa circunstancia particular se interpola, como vimos, una acción por demás significativa: los caballeros se acercan al cuerpo del rey caído y llenan su boca de tierra. En este punto, el contraste entre el conjunto de las crónicas y la fazaña es más que sugerente. En todas las crónicas del corpus bajo examen se especifica que los restos mortales del rey fueron llevados al monasterio de Santa María la Real de Nájera cuya construcción, tal y como aclaran varios de los testimonios, promoviera el propio rey. ${ }^{\circ}$ En definitiva, la secuencia que denominamos "Entierro con honores de García III" destaca en todo el corpus el carácter devoto del rey de Navarra y manifiesta la continuidad de la corona, a la vez que cierra formalmente el episodio de Atapuerca. Como expresión de continuidad dinástica y celebración de la memoria del rey, el entierro de García III en el monasterio de Santa María de Nájera constituyó en su día un modo de fortalecer la legitimidad de la dinastía Jimena de Pamplona, y su representación historiográfica posterior, un modo de consolidar simbólicamente la institución monárquica. El cuerpo natural de García III descansará en suelo consagrado, mientras que el cuerpo espiritual y político del rey continuará intacto en la obra de los reyes que le seguirán en el trono. Asimismo, la muerte del rey determinará formalmente el final del texto en la crónica real, subgénero historiográfico que se consolida en Castilla precisamente en los albores del siglo XIV (Gómez Redondo 2OOOa).

Dadas las implicancias simbólicas y políticas que trae aparejadas, la completa eliminación de esta secuencia en la fazaña es por demás significativa. La negociación entre los sectores de poder y el

28. Omitir la intervención del ayo implica además, y paradójicamente, suprimir en un plano simbólico una instancia de mediación de las relaciones políticas que se llevaba a cabo a partir del consejo, función exclusiva de los "privados de los reyes", es decir, de la nobleza más cercana al monarca.

29. Únicamente la Historia silense refiere a la venganza de los caballeros emparentados con Bermudo III como propósito del ataque a García III (“comunem sibi sanguinem vindicare singulariter anelabant”). El Toledano y la tradición castellana no hacen explícita esta intención, aunque sí describen a los caballeros como parte del séquito del rey de León ("quidam milites, qui fuerant ex familia Veremundi”; la "compaña del rey don Vermudo" en las versiones castellanas).

30. Transcribimos a continuación solo los pasajes más relevantes de las crónicas de nuestro corpus. Historia silense: "Corpus vero Garsie regis in ecclesia beate Marie Nazarensis sepulture traditur, quam ipse a fundamento devote construxerat, atque argento et auro sericisque indumentis pulchre ornauerat” (Pérez de Urbel-González Ruiz-Zorrilla ed. I959: I88); De rebus Hispaniae: “Tunc rex Fernandus precepit corpus regis Garsie honorifice Anagarum deportari et in monasterio sancte Marie, quod ipse construxerat et donariis plurimis adornauerat, sepeliri” (Fernández Valverde ed. I987: I89); Versión retóricamente amplificada de 1289: "Estonce otrossi el rey don Fernando mando leuar el cuerpo del rey don Garcia onrradamientre pora Naiara; et fue enterrado en un monesterio de Santa Maria que fiziera el mismo y enrriqueciera de muchos donadios” (Menéndez Pidal ed. I955: 485).

Magnificat CLM 7, 202O, I-43. ISSN 2386-8295 
monarca que se llevaba a cabo ante la inminencia de un enfrentamiento armado era relativamente habitual, y formaba parte de los acuerdos políticos y de la implementación concreta del lazo feudal durante la Edad Media. Y de acuerdo con los testimonios bajo examen, la batalla de Atapuerca no habría sido una excepción. En la versión cronística, las tratativas de los nobles se presentan ante García de manera paulatina, mientras que en la fazaña las demandas de los caballeros navarros se presentan sin mediaciones, abrupta y sintéticamente, una sola y única vez ("Et vinieron al rey et pidiéronle merçed que les dexasse su heredat"). La fazaña modifica el punto de vista, dado que los caballeros son en rigor los protagonistas de la fazaña, y su único oponente es el rey de Navarra. En efecto, son estos hidalgos navarros quienes llevan adelante la acción y se convierten en dos agentes de la historia cuyo nombre propio, detalle no menor, se recupera en el texto, a pesar de que no se encuentren en las crónicas del corpus examinado ni en ninguna otra documentación de la época. ${ }^{3 \mathrm{r}}$

En consecuencia, el desenlace del núcleo narrativo de esta versión no reside en la resolución del conflicto entre los reinos, sino en la restitución de las heredades a los caballeros, que se lleva a cabo luego de la muerte de García III. Las palabras de los hidalgos cierran la primera sección dedicada a la batalla con una suerte de refrán o sentencia que, casi a la manera del contrapaso dantesco, signa un castigo a la codicia del rey de Navarra. Como vemos, la envidia de García III hacia Fernando I, que la tradición historiográfica había insistido en señalar como principal motivo de la batalla, se convierte en esta versión en la codicia del navarro que tiene como objeto no el territorio del rey de Castilla y León, sino las heredades de los nobles en el propio reino de Navarra. Si en la versión cronística un rey envidia a otro rey (un sujeto, a otro), en este caso, en cambio, el rey codicia los bienes de los nobles (un sujeto, a un objeto).

Por otra parte, el discurso directo que expresa el disenso de los caballeros y confronta con la voluntad del rey, tiene lugar no en el espacio regulado y sosegado de la corte regia como en el corpus cronístico, sino en medio del fragoroso campo de batalla. Las palabras de los caballeros, lejos del discurso mesurado del ayo de García, constituyen la manifestación de una saña nobiliaria, una respuesta a los excesos del rey de Navarra en el corpus historiográfico que bien puede concebirse como contraparte de la ira regis. La voz y la justicia de los nobles (de las que los caballeros navarros son parte y juez) se liberan y ponen en marcha luego del desnaturamiento, esto es, una vez rotos los vínculos jurídicos que ataban a los nobles con su señor. La violencia que se desata luego sobre el cadáver de García III tendrá como consecuencia no el castigo a quienes la perpetraron, sino la restitución de las heredades al uso y a la propiedad de los caballeros navarros, la recomposición de las relaciones naturales y el restablecimiento de los vínculos jurídicos entre los nobles y el rey (ahora Fernando I de Castilla), en el marco del pacto feudo-vasallático tradicional según los términos ideales de la concepción señorial del ejercicio del poder.

En este punto, el discurso directo en esta segunda sección no lleva a un desenlace esperable (el castigo de un presunto delito, en los términos que el género fazaña estipula en tanto texto jurídico), sino a un retorno a la situación inicial, a una vuelta a empezar en la que los caballeros navarros realizan una nueva petición ante el nuevo rey: "Mas otro día, que estos cavalleros vinieron al rey don Ferrando e dixieron: 'Señor, fazednos merçed por el servicio que vos fiziemos ayeri'. Et él dixo:

3I. El nombre propio del atacante se recupera también en la versión de la batalla incluida en los Anales compostelanos, pertenecientes, desde luego, a una tradición discursiva totalmente diferente. En este texto se adjudica la muerte del rey García a Sancho Fortúnez, un noble navarro cuya esposa habría sido deshonrada por el rey de Navarra (Ap. IV, núm. 3): “Era mxcii occisus est Garsias rex, kalendas septembris, depugnans cum fratre suo rege $\mathrm{F}<$ erdinandus $>$ in Ataporca a quodam milite suo Sancio Hortunones quia foedauerat vxorem eius” (apud Martín 20o9: 22I, nota I52). Al respecto, José María Lacarra señala: “Los nombres de estos caballeros eran Martín Peres y Dia Peres de Barsina, nombres que no parecen navarros, ni encuentro en ningún documento de la época” (I972: I, 250). Para la importancia de los nombres propios en el manuscrito 43I, véanse Soler Bistué 20I5 y 2016 ed.: LXXX-LXXXI. 
'Plázeme, mas nunca veades rey'. Et estas palavras que fueron sentençia” (Soler Bistué ed. 20I6: 26I).

De este modo, la eliminación y la reelaboración de diversas secuencias narrativas establece nuevas relaciones de causa y consecuencia entre ellas, reconfigurando así la estructura lógico-causal de todo el relato: si el conflicto inicial del relato reside en el pedido de los nobles, la muerte del rey no necesariamente resuelve ese conflicto inicial, de modo tal que los caballeros deben volver a realizar esa misma petición al rey de Castilla y León para obtener satisfacción a su reclamo. En la fazaña, las secuencias principales (la 4 "Demanda de fueros y heredades", la 5 "Negativa del rey" y la 8 "Muerte del rey") se encadenan causalmente según el siguiente esquema:

Sección I: $\mathrm{S}_{4}=>\mathrm{S}_{5}=>\mathrm{S}_{8}$

Sección II: $\mathrm{S}_{4}{ }^{\prime}=>-\mathrm{S}_{5}=>-\mathrm{S} 8$

De esta manera, el ataque al rey de Navarra se reinterpreta a la luz de las palabras finales de Fernando I no como una venganza por la muerte de Bermudo III o por la confiscación de heredades, sino como un servicio para el rey de Castilla y León; y la muerte de García III, no como un avatar propio del combate sino como consecuencia de su negativa a la demanda de los caballeros. Y de acuerdo a la singular concatenación lógico-causal de las secuencias y al efecto de sentido que la misma imprime al relato, la restitución de las heredades a los nobles navarros responde, más que a una decisión del rey, al restablecimiento de un orden social tradicional, establecido e inamovible, que requiere, sin embargo y paradójicamente, el derrocamiento del rey de Navarra.

\subsection{A rey muerto, rey puesto. Historiografía y profanación}

Por otra parte, no sería exagerado calificar la vejación de los restos mortales del rey de Navarra como una profanación. El concepto de profano, tanto como su oposición al concepto de sagrado (tradicionales en la historia de las religiones), puede ser muy provechoso en el campo de la historia política y de las instituciones en la Edad Media castellana. Si lo sagrado es aquello que, sustraído a la esfera del derecho, pertenecía de algún modo a los dioses, lo profano, en cambio, se concibe como aquello que, habiendo sido sagrado o religioso, es retirado del templo y del espacio sagrado y restituido al uso y a la propiedad de los hombres (Borgeaud ı994: 390; Agamben 2005: 97). La representación del cuerpo del rey ultrajado puede considerarse una respuesta al proceso de sacralización de la persona del monarca, que desde fines del siglo XIII constituyó en Castilla una política concreta a partir de los reinados de Alfonso X y Sancho IV. ${ }^{32}$ Y si bien, tal y como señalara Adeline Rucquoi, Castilla no siguió el mismo derrotero que Francia e Inglaterra en el proceso de sacralización de sus reyes (1992), para el momento de puesta por escrito de esta versión, la monarquía castellana había reafirmado el camino iniciado por el Rey Sabio y su hijo, luego de la singular ceremonia de unción de Alfonso XI en I332 en Burgos en la que el rey se colocó a sí mismo

32. En su Speculum regum (I340), dedicado precisamente a Alfonso XI, Álvarez Pelayo, que cuestionaba los poderes de sanación de los reyes franceses e ingleses, destacó los poderes sobrenaturales de los reyes castellanos, en especial el talento exorcista de Sancho IV: "Reges Francie et Anglie habere dicuntur virtutem; et reges devnti Yspaniae a quibus descendis, habere dicuntur virtutem, super energuminos et super quibusdam egritudinibus laborantes, sicut vidi, cum essem puer, in avo tuo, indito domino rege Sancio, qui me nutriebat, quod a muliere demoniaca ipsum vituperante tenentem pedem super guttur eius et legentem in quodam libelo ab ea demonem expulsir et curatam reliquit" (apud Bloch 20O4: 232). 
la corona. ${ }^{33}$ Poco antes, en la primavera de ese mismo año, había sido armado caballero en Santiago de Compostela, y una estatua articulada del patrono de la ciudad fue quien le dio la pescozada. Alfonso XI reelaboraba así un ritual nobiliario de iniciación casi sagrado. ${ }^{34}$

En el contexto de la Castilla de la segunda mitad del Trescientos, representar la muerte del rey y el ultraje posterior de sus despojos a manos de dos nobles navar ros adquiere indudablemente una dimensión simbólica: por esos mismos años, poco antes o poco después de la composición del manuscrito 43I, Enrique II de Castilla, "el de las mercedes", atravesaba con un puñal el rostro de Pedro I en Montiel. El texto participa indudablemente del clima de inestabilidad política que propició las condiciones de esa guerra fratricida, y no de manera imparcial o desapasionada. En efecto, en virtud de la impronta jurídica que la forma fazaña le asigna al relato, esta versión presenta y reelabora un episodio historiográfico bien conocido como un antecedente jurídico y permite de este modo explicar el regicidio en los términos básicos y tradicionales de una ruptura de los vínculos feudo-vasalláticos entre el señor y sus vasallos, a la vez que actualiza y legitima un modelo de respuesta y de acción para los nobles del reino.

El pasaje del género historiográfico a un tipo textual jurídico implica, además, una reelaboración de los patrones formales de escritura del relato. El episodio, extraído del gran relato de la historia, despojado de esos paratextos y desquiciado de su sentido primigenio (descoyuntado, en fin), se ve sometido a un nuevo uso que privilegia la fuerza prescriptiva del relato más que su dimensión didáctica al señalar no tanto lo que sería bueno y encomiable hacer, sino lo que debiera hacerse en situaciones análogas. En el caso de la fazaña, la ejemplaridad parece responder, en definitiva, a un principio de orden ético-político. No se destaca y reivindica, como en el corpus cronístico, tanto un valor moral inherente a la nobleza (la fidelidad), sino más bien una atribución o prerrogativa propia del estamento nobiliario fundada e instituida jurídicamente: el desnaturamiento, la facultad de romper unilateralmente el vínculo vasallático como forma de pronunciarse ante la injusticia del señor, y como expresión del disenso político (tal como hiciera, por ejemplo, don Juan Manuel con Alfonso XI hacia I327). Frente a la conducta ejemplar del ayo, que llevaba a cabo un abnegado sacrificio para expresar su desacuerdo sin romper el vínculo con su señor, los caballeros navarros

33. La excepcionalidad de la ceremonia de unción de Alfonso XI fue advertida por Claudio Sánchez-Albornoz (I976: I22I), quien señaló además que el rey se había apartado de lo que prescribía el ceremonial redactado por el obispo de Coimbra para esa misma ocasión (I976: ı223). José Manuel Nieto Soria (ı987: 2, I227; ı988: 63-35 y IOO; ı997, entre otros trabajos), por su parte, ha analizado los procesos de resacralización y las distintas alternativas sacralizadoras que se llevaron a cabo especialmente en la segunda mitad del siglo XIII: la elaboración jurídico-teológica del tomismo supuso la sacralización del poder público y de la persona del rey, el “intérprete natural” de lo que es efectivamente el bien público, configurando así lo que denomina una “ideología de la realeza sagrada”. Uno de los rasgos destacados de esta ideología fue, pues, la divinización de la realeza. La descripción que Nieto Soria traza para el siglo XIII destaca en este proceso el papel de Alfonso X y de Sancho IV y centra su interés en la caracterización teocrática del poder real y su desarrollo, así como en el pasaje de un modelo cristocéntrico a uno teocéntrico. Según este último modelo, el monarca no era concebido a imagen de Cristo en la tierra representando a Dios en sus dos naturalezas sino, ya sin mediaciones, imagen de Dios; no un signo de otro signo, sino un signo de otra cosa, relativizando así la importancia de la unción real (Nieto Soria 1997: 49-5I y 69). Es esta última una cuestión sometida a discusión. Entre quienes han objetado las hipótesis de Nieto Soria se encuentra, además de la ya citada Adeline Rucquoi (I992), Peter Linehan, quien ha criticado con especial énfasis la relativización de la ceremonia de unción real en público de los monarcas castellanos que Nieto Soria lleva a cabo (I993: 453-454).

34. Como notara el propio don Juan Manuel en el Libro del cavallero et del escudero, "Et otrosí por que desta orden et deste estado son los reys et los grandes sennores; et este estado non puede aver ninguno por si, si otro non gelo da, et por esto es commo manera de sacramento. Ca bien así commo los sacramentos de la sancta Eglesia an en si cosas çiertas, sin las quales el sacramento [non] puede seer conplido, ansí la cau[a]lleria a mester cosas çiertas para se fazer commo se deve... A mester que sea y el señor que da la caualleria et el cauallero que la reçine et la spada con que se faze" (Blecua ed. г981: 44-45). 
deciden desnaturarse y atacar al rey de Navarra y profanar su cuerpo, no solo para expresar un desacuerdo, sino también y fundamentalmente para recuperar sus heredades, objetivo último de esta historia.

La reescritura de este episodio implica, por tanto, la reactivación del discurso histórico: el relato de Atapuerca se sustrae de la tradición historiográfica en la que su estructura narrativa básica se había sedimentado a lo largo de varios siglos, para restituirle un uso político plenamente involucrado con el presente de su escritura. Esta operación constituye, en cierta medida, un acto de profanación semejante, aunque de distinta intensidad, al que realizara el Toledano más de cien años antes al añadir al texto de la Silense las secuencias del pedido de heredades y la del ayo. Y como señalara Roland Barthes oportunamente en un texto clásico, "la profanación de las reliquias es, de hecho, la destrucción misma de la realidad a partir de la intuición de que la realidad no es nunca más que un sentido, revocable cuando la historia lo exige y reclama una auténtica subversión de los fundamentos de la civilización” (ı994: I76). ¿No constituye acaso la escritura de la historia un acto de profanación? ¿Y no se apela en ocasiones a los valores más nobles, las tradiciones más inveteradas y a las leyes más firmes para realizar los actos más abominables?

\subsection{Estorias nobiliarias, escritura novelesca}

Los sucesos relativos a la batalla de Atapuerca (y, por extensión, a la historia de los reinos hispanocristianos) parecen haber quedado al margen de la acción propiamente dicha, sirviendo apenas de telón de fondo para enmarcar el conflicto que moviliza la historia: el enfrentamiento entre el estamento nobiliario y la monarquía. De la versión transmitida en las distintas crónicas a lo largo de la primera mitad del siglo XIV apenas subsisten algunos motivos: la petición de los caballeros y la negativa del rey, el ataque desde una posición elevada (un cabesço, en este caso), la dupla de caballeros. Ahora bien, ¿de dónde proceden los cambios? Es difícil imaginar que los copistas ignoraran las versiones cronísticas previas del relato de la batalla de Atapuerca. ¿Son estas modificaciones producto de la libre iniciativa de los compiladores de estas colecciones de derecho señorial? ¿Habría existido una tradición oral paralela a la tradición historiográfica escrita de la que no se conserva antecedente alguno ni su evolución posterior?35 El texto pareciera ofrecer indicios de la existencia de fuentes de diversa naturaleza e incluso de otras versiones: al terminar la batalla, el narrador afirma la veracidad de lo que acaba de contar basándose en dos fuentes: la fazaña y la palabra de los consejeros del rey ("Et fasta aquí dize la fazaña de los fijos dalgo et dizen los privados de los reyes, que an de guardar su razón, que verdat es que asý pasó”). La fazaña no contradice la versión historiográfica contenida en las grandes crónicas de los reyes de Castilla, sino que ofrece un peculiar enfoque de la batalla de Atapuerca, aquel que refiere esa "fazaña de los fijosdalgo" cuya validez se ve confirmada por la palabra de los privados de los reyes. Esta versión privilegia una secuencia, la amplifica ofreciendo todo tipo de detalles y completa el gran relato de la Historia incorporando y centrándose en aspectos marginales que el decorum historiográfico habría omitido, y llevándonos en consecuencia a ver la misma acción desde otro punto de vista, a contemplar esos mismos acontecimientos desde otro lugar y con otros ojos.

El meollo del relato consiste no en la muerte del rey de Navarra, sino en la restitución de las heredades de dos caballeros navarros. Esta temática general enlaza perfectamente con la leyenda de los Jueces de Castilla y con otros relatos recopilados en este códice: la autonomía del estamento

35. Con respecto al origen oral del derecho consuetudinario al que se remonta la legislación por fazañas en Castilla, véase Paul Zumthor (I989: ı05) y, para el caso específico de los fueros castellanos, Johannes Kabatek (I999: I78-I79).

Magnificat CLM 7, 202O, I-43. ISSN 2386-8295 
nobiliario. En este sentido, la muerte del rey García III contribuye, como condición necesaria pero no suficiente, a restituir un orden ideal, y su asesinato no constituye en rigor una profanación, sino un acto sacrificial socialmente necesario en el esquema de valores que el texto presupone, actualiza y vuelve a instituir; y también constituye el primer paso de una serie de acontecimientos que tienden a restablecer el equilibrio del relato y de la historia. El rey continúa siendo el principio ordenador que organiza el sistema de significación del relato -la instancia semiótica de mediación dominante, en términos de Georges Martin (Martin I997: 54)-; pero este principio ordenador, este lugar soberano de la significación, se ajusta, se negocia y modifica en virtud de la acción de otros agentes que indudablemente inciden en la actualización del sentido del texto. En efecto, el equilibrio narrativo que lleva al desenlace en esta versión (que se corresponde, en el plano del enunciado, con una situación de armonía social y concordia política) se alcanza en virtud de la acción de los caballeros navarros que eliminan a un personaje, García III; es decir, a la persona física del rey, pero de ningún modo a la persona espiritual del monarca ni tampoco su función social y política. “¡El rey ha muerto, que viva el rey!”, parece exclamar el texto; pero no cualquier rey. Esta figura debe responder a un modelo que se configura de acuerdo a los ideales propios de la concepción señorial del ejercicio del poder que describimos más arriba. Y este lugar soberano de significación hacia el interior del texto se ve necesariamente modelado por la instancia de enunciación, la voz narrativa que organiza y presenta los acontecimientos narrados.

Los procedimientos formales que la versión contenida en el manuscrito 43I despliega a partir de la materia tradicional son dos y complementarios: por un lado, una selección y recorte tanto de elementos paratextuales (que en virtud del tipo textual empleado se reducen a una mínima expresión) como de determinadas secuencias narrativas y, en consecuencia, una redefinición del núcleo del relato en virtud de dicha selección; por otro lado, la expansión de secuencias y la inserción y desarrollo de ciertos detalles. Estas operaciones imprimen al texto un sesgo novelesco en el que el discurso historiográfico pierde el decorum propio del género, a la vez que el patetismo gana intensidad. Ahora bien, la agitación de las pasiones de la versión incluida en el manuscrito 43I no pareciera tener la misma función que la que encontramos en otras versiones. El sacrificio del ayo, como vimos, pone de manifiesto tanto la palmaria injusticia que García de Navarra estaba llevando a cabo como la reafirmación de la ira ciega que conducía las acciones de este rey. Esta secuencia, eliminada en la fazaña, representa a este personaje como un monarca injusto, obcecado e iracundo, y despliega los fundamentos para la condena moral del rey. La batalla posterior y su muerte son consecuencias al menos narrativamente esperables y socialmente admisibles..$^{36}$ De este modo, el sistema de valores que rige una conducta ideal y que, en virtud de la injusticia de los actos de su señor, lleva al ayo a una drástica decisión, se expresa aquí plenamente, y deja al rey García expuesto ante sus súbditos y ante el lector de modo tal que los trágicos sucesos de la batalla de Atapuerca se explican en el corpus cronístico fundamentalmente por la deficiencia moral del rey. La fazaña, en cambio, no despliega un principio explicativo para los grandes acontecimientos del reino, sino que se centra en un conflicto secundario, en apariencia menor del que convoca a las huestes al campo de batalla, pero que será decisivo en su desenlace y para la historia de los reinos.

Es en los márgenes de la historia, en sus personajes menores y sus episodios fortuitos, donde pueden hallarse las causas a los acontecimientos más resonantes y trascendentes. Y es precisamente allí, en esos espacios textuales, donde la fazaña y las estorias nobiliarias despliegan sus esfuerzos para completar el gran relato de la historia.

36. Ya a mediados del siglo XII y desde una perspectiva teológico-política, el Policraticus de Juan de Salisbury había generado las condiciones necesarias para una reflexión teórica en torno a la legitimidad de los casos de tiranicidio (Salgado Loureiro 20I6; Nieto Soria 2OI7). 
La fazaña es escritura novelesca no solo en virtud del color local y las inveteradas costumbres que presumiblemente recrea, ${ }^{37}$ sino también, y fundamentalmente, debido a que instituye una experiencia de lectura: la escritura de la historia lleva a cabo una actualización homeostática del pasado y fuerza hasta el límite ciertos patrones propios del género historiográfico haciendo del relato (no de su desenlace, sino de su relación) algo menos predecible.

Diego Catalán ha descrito este fenómeno de novelización del discurso historiográfico postalfonsí como un proceso de enriquecimiento del discurso histórico a partir de la incorporación de "abundantes escenas en que la vida bulle y en que los actores piensan y sienten a nuestra vista" (I969: I, 428). En este mismo sentido y para el periodo denominado post-alfonsí, Inés FernándezOrdóñez ha señalado que "el camino de la novelización" menos erudita, poco respetuoso con la verdad histórica, se dio en ambientes monásticos y laicos (I993: I28). En este último caso, obras como la *Historia nobiliaria (también hoy perdida), la Historia menos atajante, la Historia hasta 1288 dialogada o la Crónica de Castilla (que "representa a la perfección esta corriente"), "fueron realizadas en ambiente laico para favorecer diversos intereses, pero sobre todo a la triunfante clase nobiliaria que consiguió derrocar a Alfonso [X]” (Fernández-Ordóñez 1993: I29). ${ }^{38}$ Filipe Alves Moreira, por su parte, ha señalado que esta tendencia a la novelización (a la que denomina "ficcionalización" del discurso historiográfico) responde a un propósito general de completud del relato histórico como requisito de veracidad del texto; por otra parte, este proceso de ficcionalización implicó una progresiva reconfiguración de las normas de conducta y de valores ideológicos, y dio lugar a una progresiva afirmación de las prerrogativas nobiliarias con el propósito manifiesto de equipararse con (aunque no de suplantar a) la monarquía (Alves Moreira 20I5: I, 236237).

Llegados a este punto, resulta necesario plantear una serie de interrogantes para ordenar el recorrido que acabamos de llevar a cabo y presentar algunas conclusiones que atañen a esta última versión y a la escritura historiográfica hacia la segunda mitad del Trescientos. Vistas las singularidades de la fazaña incluida en el manuscrito 43I de la Biblioteca Nacional de España, ¿quién es el que habla en este texto? ¿Qué función cumple la voz que rige y ordena el relato de los hechos de Atapuerca? ¿Sobre qué autoridad funda sus juicios y las variantes del relato? ¿Responden estas a necesidades de la Historia o de la historia? ¿Se trata acaso de las exigencias de un género, de una poética 0 , por el contrario, de fidelidad a los hechos, a los hechos tal y como los percibe una determinada comunidad textual? En este sentido, ¿qué tipo de subjetividad historiográfica y de perspectiva configura este relato? ¿Cuál es su punto de vista?

\section{Historiografía, semiótica, ideología}

$\mathrm{H}_{\mathrm{s}}$ emos señalado más arriba que cada una de las crónicas del corpus se enmarcó en una ideología historiográfica específica que acompañó un proyecto político y cultural. Ahora bien, la ideología historiográfica no solo debe considerarse como un sistema de ideas consistente y explícito en torno

37. Esta concepción de la costumbre jurídica debe ser tomada con cautela. Para una revisión crítica de esta perspectiva, véase Miceli (2OI2).

38. Patricia Rochwert-Zuili ha analizado la función de los afectos en el sistema de legitimación en la Crónica de Castilla, aunque sitúa su composición en el marco de la corte de María de Molina, y señala como propósito general del texto la afirmación del poder real. El proceso de novelización (que nos interesa destacar especialmente en este recorrido en torno a la batalla de Atapuerca) habría sido fundamental para persuadir y provocar en los destinatarios mediante las emociones allí representadas la adhesión a "las orientaciones sociopolíticas del relato” (2OI7: §2).

Magnificat CLM 7, 202O, I-43. ISSN 2386-8295 
a una problemática histórico-política en el mismo sentido que la ideología a secas no es únicamente propaganda o "falsa conciencia". El sesgo ideológico de un texto puede tener también implicancias en la forma de escribir la historia, es decir, en los parámetros formales de configuración del discurso historiográfico que constituye e involucra una dimensión de lo social que no puede ser suprimida. La reelaboración de la materia de Atapuerca reproduce el sistema de ideas y valores compartidos por toda la sociedad (que incluye, desde luego, tanto al ámbito de la corte regia como a la alta y baja nobleza), pero cada actualización (de mayor o menor intensidad) inscribe el presente en el texto imprimiendo las particularidades de su configuración simbólica. Y esta actualización se lleva a cabo a su vez en virtud de una interpretación de los hechos, un sistema de valores y una cosmovisión que se actualizan y permiten revalidar la significación social e histórica del episodio para una comunidad textual concreta en un momento histórico determinado.

Nuestro objeto principal fue poner de relieve la singularidad de los matices que describimos y analizamos en la fazaña de dos maneras: primero, en contraste con la tradición historiográfica previa; en segundo lugar, teniendo en consideración la ingente conflictividad del momento de composición del texto, de las colecciones que lo incluyen y del códice que las contiene.

En este sentido, es posible dilucidar no solo cuál es el conflicto político-jurídico a cuya sombra, a mediados del siglo XIV, se escriben estos textos - un episodio de lo que José Manuel Pérez Prendes y Muñoz de Arraco definió acertadamente como una guerra civil sorda y episódica pero permanente, que enfrentó dos proyectos de arquitectura política (1989: 479; citado in extenso en la nota 20)-, sino también quiénes son los agentes sociales que aquí se expresan, qué instituciones hacen posible su puesta por escrito y qué imaginario se plasma en estas líneas. En tiempos de Alfonso XI, el proyecto de centralización monárquica parecía afianzado luego de la promulgación del Ordenamiento de Alcalá en I348. Sin embargo, la inesperada muerte del rey en I35O, a causa de la peste negra durante el asedio de Gibraltar, modificó las condiciones de este proceso. La manifestación más clara de esta reacción en los comienzos del reinado de Pedro I se plasma en los reclamos por derechos nobiliarios que llevaron al joven rey, en las Cortes de Valladolid de I35I, a comprometerse a la realización de un relevamiento catastral de las behetrías, es decir, un ordenamiento jurídico de heredades y señoríos naturales de hidalgos. En estas cortes los hidalgos presentaron al rey don Pedro I, entre otras, la siguiente petición:

que veyendo ellos quelos omeziellos e muertes e peleas e contiendas que entre ellos han acaesçido fasta agora, que lo mas dello fue e es por las behetrias que ovieron, e que agora por se partir delas dichas peleas e contiendas (...), acordaron quelas behetrias sean departidas entre los naturales dellas e quelas ayan cada uno de los naturales lo quele y copiere por los solariegos.

(Real Academia de la Historia ed. I863: 2, I37)

Esta solicitud dio lugar a la constitución, el 29 de agosto de I35I, del Ordenamiento de los fijosdalgo, y posteriormente a la pesquisa que sentó las bases para la elaboración del Libro del becerro de las behetrías (Clavero 1974; García León I999: 340; Estepa Díez 2007: I38). Esta discusión en cortes puso de manifiesto las contradicciones en el interior de la nobleza, y los crecientes enfrentamientos intraestamentales que derivarían en la guerra civil (ı366-г369) que culminó con la muerte de Pedro I en Montiel. El canciller Pero López de Ayala da cuenta del reclamo nobiliario en Valladolid cuyo principal portavoz fue don Juan Alfonso de Alburquerque, hombre de máxima confianza del rey, caído en desgracia luego de este episodio (Orduna ed. 1994: 49-5ㅍ). La discusión de fondo se centraba en la aceptación del principio de naturaleza que regiría las relaciones 
entre los nobles y el rey, es decir, si los nobles aceptarían el señorío natural del monarca. ${ }^{39}$ Por otra parte, no debería obviarse que la animadversión de la dinastía Trastámara hacia Pedro I "el Cruel” llegó a los extremos de destruir las huellas documentales e historiográficas de su reinado. En este sentido, la construcción de personaje que la historiografía latina realizó de manera incipiente sobre la persona de García III es similar a la que durante los primeros siglos de la Modernidad se llevó a cabo sobre la figura de Pedro I, y sobre la que todavía hoy se entabla una contienda historiográfica que ha dado lugar incluso al reconocimiento de una "historiografía petrista" (Valdaliso Casanova 2OI2; Rodríguez Porto-Roselló Martínez 2OI7).

En suma, los eventos desencadenados en los años posteriores a las cortes celebradas en Valladolid en I35I llevaron a la trágica sucesión dinástica en favor de Enrique II, y constituyeron el contexto casi inmediato de composición del manuscrito 43I de la Biblioteca Nacional de España. Precisamente en este códice se conserva la colección de fazañas entre las que se encuentra, en lugar destacado, aquella que nos ocupa en esta oportunidad.

Las variantes de la versión transmitida en la fazaña, junto con los factores contextuales brevemente reseñados, constituyen indicios concretos de la emergencia de una escritura nobiliaria. La ideología historiográfica se expresa en estos textos breves mediante la recuperación fragmentaria del pasado y la autonomía episódica de ciertos motivos historiográficos tradicionales. Lo que se ensaya en esta colección de fazañas puede apreciarse también y de forma algo más acabada en las crónicas que Leonardo Funes denominó "estorias nobiliarias" (2OI5): la *Historia hasta 1288 dialogada, la Estoria cabadelante y la Crónica particular de San Fernando. En todos estos textos "se presupone una relevancia que emana de una mentalidad nobiliaria: reyes atentos al consejo de sus nobles; nobles que rinden su servicio al buen rey; caballeros que son paradigmas de conducta" (Funes, 2OI5: I72). Ahora bien, podrá objetarse que esta descripción responde por igual al ideario que se expresa en la versión de la batalla de Atapuerca consolidada en las crónicas. Y esto es así si nos atenemos únicamente a unos contenidos básicos y a una materia historiográfica tradicional. Pero, como vimos, la fazaña no solo mantiene intactos los grandes temas, sino que reaviva motivos, y recrea detalles y escenas desconocidos para la tradición. Es en esos detalles y en esas escenas donde el estamento nobiliario reafirma su poder. La potencia de esa reacción se expresa en una configuración narrativa específica (en la selección y desarrollo de algunas secuencias); en actos de habla concretos ("La tierra tomastes. Et fártate de tierra”) y amenazas veladas (precisamente al vencedor de Atapuerca, el rey Fernando I); y en un inusitado protagonismo de personajes menores (de quienes hasta se inventa el nombre) frente a los reyes en el marco de la historia de los reinos de León, Castilla y Navarra. Por otra parte, en un llamativo movimiento recursivo, la fazaña se refiere a sí misma poniendo de relieve el ejercicio soberano de una función enunciativa ("et fasta aquí dize la fazaña de los fijos dalgo...”).4 En esa voz enunciativa que aclara en los márgenes de la historiografía

39. Para la importancia jurídico-política del concepto de naturaleza a partir de la Segunda Partida, véase Bartolomé Clavero (ı976; especialmente páginas 333 y ss.) Georges Martin (2008) y José Manuel Nieto Soria (2008: §5-6, §I4-I5, $\S 42)$.

40. Una operación similar puede observarse en la fazaña anterior que funge de prólogo a toda la colección y reelabora la leyenda de los Jueces de Castilla: "Et enviaron por todos los libros que d'este fuero [el Fuero Juzgo] que avían en todo el condado et quemáronlos en la englera de Burgos et ordenaron alcalles en las comarcas que librasen por alvidrío en esta manera: que de los pleitos que acaesçían que eran buenos, que alvidriasen el mejor, et de los contrarios, el de menor daño et este libramiento que fincasse por fazaña" (Soler Bistué ed. 20I6: 26I). Esta fazaña recupera, desde luego, la materia tradicional según la cual Castilla adquiere autonomía jurídico-política respecto del reino de León en la segunda mitad del siglo IX; pero además, y esta es la singularidad de la versión contenida en el manuscrito 43I, la fazaña convierte la leyenda de los Jueces de Castilla en una narración acerca del origen de la narración por fazañas. El texto representa esta forma de administración de justicia a partir de sentencias como reemplazo al Fuero Juzgo cuyos ejemplares son incinerados en la glera de Burgos. Como vimos a propósito del Concilio de Coyanza y las Cortes de 
se manifiesta un punto de vista y una toma de posición, en definitiva, la subjetividad nobiliaria castellana.

La fazaña, la anécdota y la leyenda, formas narrativas breves derivadas del exemplum medieval que se intercalan en los innumerables pliegues y lagunas del gran relato historiográfico, se convierten en la crónica nobiliaria, tal y como observamos más arriba, en un patrón de configuración del relato histórico. Al recuperar aspectos marginales de la historia, al redimir lo presuntamente desplazado y olvidado por las crónicas anteriores, esta escritura nobiliaria constituye una reacción y una impugnación metodológica al modelo historiográfico del Rey Sabio. Si el dilema de la forma narrativa de las crónicas alfonsíes consistió en encontrar un equilibrio entre el principio de relevancia y el principio de la verdad histórica (Funes 1997: 59), la autonomía, la brevedad y la sólida consistencia interna de la fazaña como modelo constructivo permitieron ampliar el relato histórico y congregar no solo eventos marginales o anecdóticos sino también ofrecer puntos de vista alternativos dando forma de este modo a lo que bien podría denominarse, parafraseando a don Juan Manuel, el libro infinido de la historia.

Atapuerca se constituye así en signo, como un pendón en el extenso campo de batalla de la historiografía castellana de cuya potencia expresiva, adormecida en la tradición historiográfica previa, se apropia este relato. Desde el punto de vista que ofrece esta singular versión de los acontecimientos, Atapuerca se configura como un hito glorioso no ya en la historia del reino de Castilla (que ha sabido ser divina, universal o real) sino en la historia de la afirmación del estamento nobiliario frente a la monarquía, sea navarra sea castellana.

\section{${ }_{7}$ Conclusiones}

I. El relato de los hechos de Atapuerca sufrió en Castilla numerosas modificaciones desde sus primeras manifestaciones historiográficas en el corpus latino (desde la Historia silense hasta De rebus Hispaniae). La versión del Toledano introducirá variantes y será la que finalmente se consolide, ya casi sin grandes modificaciones en la historiografía castellana posterior.

2. La versión castellana subsiste casi intacta en los marcos de escritura historiográfica de mediados del siglo XIII y fines del XIV, pese a los cambios formales de configuración del relato histórico en este periodo. Cada proyecto historiográfico, más allá de los diversos propósitos y contextos de producción, recurrirá a esta misma versión, que reproducirá casi sin variantes de peso.

3. Esta materia historiográfica se vuelca, finalmente, en la segunda mitad del siglo XIV, a un molde formal de escritura jurídica de carácter señorial, la fazaña. Las variaciones que allí se manifiestan son notables, y responden tanto a los marcos genéricos propios del discurso jurídico como a patrones formales de escritura en prosa de un momento histórico específico.

4. El origen de estas variantes podría atribuirse a una instancia de oralidad ligada al derecho consuetudinario, esto es, un derecho no escrito basado en la transmisión oral de costumbres y de

Valladolid, la administración de justicia y el ordenamiento jurídico del reino constituyen el conflicto social al que los textos estarían aludiendo solapadamente. Por demás significativa es esta puesta en relación de ambos relatos, si tenemos en cuenta que ya en el Liber regum se remontaba la genealogía de Fernando I de Castilla y García III de Navarra a un común ascendiente: Nuño Rasura, uno de los jueces de Castilla. Para un estudio en detalle de esta leyenda véase Soler Bistué ed. 20I6: CXVI-CXIX. 
casos concretos hasta encontrar una formulación escrita.

5. A la luz de los argumentos expuestos a lo largo de este trabajo, las variantes relevadas en esta versión tardía de la batalla de Atapuerca también podrían explicarse aduciendo la existencia de focos de producción cultural que, en el último cuarto del siglo XIII, habrían promovido la puesta por escrito de relatos historiográficos y jurídicos de tipo consuetudinario y señorial conformando las colecciones que se reunirían en el manuscrito 43I en la segunda mitad del Trescientos (Funes 2000 y 200I; Soler Bistué ed. 20I6: LXXX-LXXXII). En definitiva, este estudio se ha abocado al análisis de un cruce específico e históricamente determinado entre mecanismos políticos y efectos de discurso en la historiografía castellana.

6. La finalidad política de estas intervenciones culturales puede explicarse en el marco de una reacción nobiliaria al proyecto de centralización política y jurídica que se puso en marcha con Alfonso X y se consolidó con Alfonso XI. Estas reacciones tuvieron momentos de especial virulencia, se llevaron a cabo en el campo de las armas (en la sublevación de Lerma en i272 y el regicidio de Pedro I en Montiel en I369) y de las letras, y encontraron fundamento en la tradición y en un ideal nobiliario.

7. Considerando un periodo amplio de acción cultural, la reacción discursiva de la nobleza conoció dos grandes momentos de puesta por escrito del derecho señorial que involucraron, primero, hacia mediados del siglo XIII, la redacción de la mayor parte de los textos de derecho señorial conservados; luego, hacia mediados del siglo XIV, la redacción del Fuero viejo en su forma sistemática (I356), y la composición del manuscrito 43 de la Biblioteca Nacional de España (I360-I380), siendo este periodo el punto culminante de la crisis política en el que se desenvolvió el violento enfrentamiento entre petristas y trastamaristas. Esta reacción cultural de la nobleza constituyó una derivación del conflicto político hacia formas discursivas de respuesta en la reelaboración del derecho señorial.

8. La colección de fazañas, por su parte, no solamente reivindica prerrogativas nobiliarias, sino que representa figuras concretas del ejercicio del poder (del que forman parte sustancial la administración de justicia y la creación de derecho) y del orden social (en el que intervienen directamente estos aspectos jurídicos) de corte aristocrático y antirregalista: esta colección formada en tiempos de Pedro I y muy probablemente ya en años de la Guerra Civil (I366-I369)dramatiza en distintos episodios narrativos la arbitrariedad jurídica y el uso de la violencia como atributos propios del estamento nobiliario, así como la autorregulación jurídica de los señores, e incluso el delito de lesa majestad.

9. Pero esta recuperación del orden tradicional no se limita a una repetición sin más. La defensa de los valores morales, la conciencia lingüística y semiótica y el ideario político de la alta nobleza castellana contra la creciente consolidación del poder político en la persona del rey, han dislocado a esa comunidad que, a fin de afianzar sus prerrogativas, recurre a la reescritura de la historia y del derecho. Esta reescritura implicó una compleja reelaboración del pasado y, paradójicamente, la reinvención de una tradición política y jurídica basada en la riqueza, la privanza, el linaje y la autonomía jurídica así como de su propia identidad social.

Io. Finalmente, la reelaboración del pasado, en un intento de aferrarse a formas y sentidos tradicionales reivindicados por la nobleza, imprimió en el discurso los rasgos formales que la fazaña expresa de manera paradigmática: concisión y brevedad en su estructura narrativa; una 
autonomía análoga a la del exemplum respecto de otros discursos; un estilo signado por la parataxis que le resta cohesión a sus partes; en cuanto a sus tópicos y temas, se produce una alteración de jerarquías al privilegiar un conflicto entre particulares por sobre los intereses y la historia de los reinos involucrados; este fenómeno de inversión puede apreciarse: en el plano del contenido; en la configuración de los personajes al atribuir el protagonismo y la centralidad de la acción a caballeros, simples fijos dalgo que se ponen en pie de igualdad ante los reyes de Castilla y Navarra; y en el interés por el detalle y el desarrollo de su potencia expresiva al exhibir, desplazando las reglas y los códigos del género, aquello que debía permanecer oculto. En definitiva, la inflexión nobiliaria del discurso historiográfico anuncia una modalidad específica de escritura novelesca en los umbrales de la Modernidad.

II. Toda vez que la reelaboración del pasado contrasta ostensiblemente con formas y sentidos socialmente aceptados y afianzados a lo largo del tiempo, el análisis semiótico del texto historiográfico puede ser de utilidad para destacar aquellos rasgos singulares en la escritura de la historia que permiten determinar el perfil ideológico de los textos más allá de sus intenciones declaradas y sus propósitos explícitos.

\section{Agradecimientos}

Quiero dar las gracias a Francisco Bautista (Universidad de Salamanca), quien me señalara, hace ya unos cuantos años, la singularidad de la fazaña respecto de las versiones cronísticas de la batalla de Atapuerca. También debo agradecer a Aengus Ward (University of Birmingham) y Manuel Hijano Villegas (Durham University) el haberme acercado materiales y sugerencias que fueron de gran ayuda para el desarrollo de este trabajo. 


\section{${ }_{9}$ Obras citadas}

Agamben, Giorgio. 2005. 'Elogio de la profanación’, in Profanaciones (Buenos Aires: Adriana Hidalgo), pp. 97-II9

Alves Moreira, Filipe. 20I5. 'Processos de ficcionalização do discurso nos relatos cronísticos do reinado de Afonso VIII de Castela', in Literatura y ficción: "estorias", aventuras y poesía en la Edad Media, ed. by Marta Haro Cortés, 2 vols (València: Publicacions de la Universitat de València), pp. 225-239

Ankersmitt, Frank R. 20I4. Historia y tropología: ascenso y caída de la metáfora (Buenos Aires: Fondo de Cultura Económica)

Barthes, Roland. I994. 'El discurso de la historia', in El susurro del lenguaje (Barcelona: Paidós), pp. I63-I77

Baury, Ghislain. 20II. 'Los ricoshombres del rey en Castilla: el linaje Haro (IO76-I322)', Territorio, Sociedad y Poder, 6: 53-72

Bermejo Cabrero, José Luis. I972. 'Fazañas e historiografía', Hispania, 32: 6I-76

Besga Marroquín, Armando. 2009. 'La batalla de Atapuerca', Letras de Deusto, 39.I24: 9-62

Blecua, José Manuel (ed.). I98ı. Don Juan Manuel Obras Completas I (Madrid: Gredos)

Blecua, José Manuel (ed.). 1983. Don Juan Manuel Obras Completas II (Madrid: Gredos)

Bloch, Marc. 2004. Los reyes taumaturgos (México: Fondo de Cultura Económica)

Borgeaud, Philippe. 1994. 'Le couple sacré/profane: Genèse et fortune d'un concept “opératoire” en histoire des religions', Revue de l'Histoire des Religions, 2II.4: 387-418 < https:/ / doi. org/IO.3406/rhr.I994.1385>

Campa, Mariano de la. 2003. 'Crónica de veinte reyes', Revista de Literatura Medieval, I5.I: I4I-I89

Campa, Mariano de la. 2005. 'La Estoria de España de Alfonso X: la Versión crítica en los primeros reyes castellanos', in Actas del X Congreso Internacional de la Asociación Hispánica de Literatura Medieval, ed. by Josep Lluís Martos Sánchez, Josep Miquel Manzanaro i Blasco, and Rafael Alemany Ferrer (Alacant: Institut Interuniversitari de Filologia Valenciana), pp. 469-486

Campa, Mariano de la (ed.). 2oog. La 'Estoria de España' de Alfonso X: estudio y edición de la 'Versión Crítica' desde Fruela II hasta la muerte de Fernando II (Málaga: Universidad de Málaga)

Catalán, Diego. 1966. 'El Toledano romanzado y las Estorias del fecho de los godos del s. Xv', in Estudios dedicados a James Homer Herriott (Madison: University of Wisnonsin), pp. 9-IO2

Catalán, Diego. 1977. 'Don Juan Manuel ante el modelo alfonsí: el testimonio de la Crónica abreviada', in Juan Manuel Studies, ed. by Ian MacPherson (London: Tamesis), pp. I7-5I

Catalán, Diego. I969. 'Poesía y novela en la historiografía castellana de los siglos XIII y XIV', in Mélanges offerts à Rita Lejeune, 2 vols (Gembloux: Duculot), I: 423-44I

Catalán, Diego. 1992. La "Estoria de España" de Alfonso X. Creación y evolución (Madrid: Fundación Menéndez Pidal; Universidad Autónoma de Madrid)

Catalán, Diego. 1997. De la silva textual al taller historiográfico alfonsí: códice, crónicas y cuadernos de trabajo (Madrid: Fundación Menéndez Pidal; Universidad Autónoma de Madrid) 
Clavero, Bartolomé. 1974. 'Behetría I255-I365: crisis de una institución de señorío y de formación de un derecho territorial en Castilla', Anuario de Historia del Derecho Español, 44: 2OI-342

Clavero, Bartolomé. r976. 'Notas sobre el derecho territorial castellano, I367-I445', Historia, Instituciones, Documentos, 3: I4I-I65

Dahan, Gilbert. I999. L'exégèse chrétienne de la Bible en Occident médiéval: XIT-XIV siècle (Paris: Les Éditions du Cerf)

Estepa Díez, Carlos. 2007. 'Hombres de benefactoría y behetrías en León (siglos XI-XIV): aproximación a su estudio', in El lugar del campesino en la obra de Reyna Pastor, ed. by Ana Rodríguez (València: Publicacions de la Universitat de València; Madrid: CSIC), pp. II3-I4O

Estévez Sola, Juan (ed.). 2003. Crónica Najerense (Madrid: Akal)

Falque, Emma (ed.). 2003. Lucae Tvdensis opera omnia, Tomvs I: Chronicon Mundi (Turnhout: Brepols)

Fernández Valverde, Juan (ed.). I987. Roderici Ximenii de Rada Historia de rebus Hispaniae sive Historia gohtica (Turnhout: Typographi Brepols Editores Pontificii)

Fernández Valverde, Juan (ed.). 1989. Rodrigo Jiménez de Rada Historia de los hechos de España (Madrid: Alianza)

Fernández-Ordóñez, Inés. 1992. Las 'Estorias' de Alfonso el Sabio (Madrid: Istmo)

Fernández-Ordóñez, Inés. I993. 'La historiografía alfonsí y post-alfonsí en sus textos. Nuevo panorama', Cahiers de Linguistique Hispanique Médiévale, I8-I9: IOI-I32 < $\underline{\text { https:/ / doi. }}$ org/I0.3406/cehm.1993.1084>

Fernández-Ordóñez, Inés. 1999. 'El taller historiográfico alfonsí: la Estoria de España y la General estoria en el marco de las obras promovidas por Alfonso el Sabio’, in El Scriptorium alfonsí: de los libros de astrología a las 'Cantigas de Santa María', ed. by Jesús Montoya Martínez and Ana Domínguez Rodríguez (Madrid: Fundación Universidad Complutense), pp. IO5-I26

Fernández-Ordóñez, Inés. 2OOO-200I. 'Novedades y perspectivas en el estudio de la historiografía alfonsí, Alcanate: Revista de Estudios Alfonsíes, 2: 283-300 < $\underline{\text { https://hdl.handle. }}$ net/II44I/823I5 $>$

Fita Colomé, Fidel. ı895. 'Santa María la Real de Nájera: estudio crítico’, Boletín de la Real Academia de la Historia, 26: I55-I98

Fortún Pérez de Ciriza, Luis Javier. 2005. 'Monjes y obispos: la Iglesia en el reinado de García Sánchez III el de Nájera', in García Sánchez III 'el de Nájera': un rey y un reino en la Europa del siglo XI, ed. by José Ignacio de la Iglesia Duarte (Logroño: Instituto de Estudios Riojanos), pp. I9I- $25^{2}$

Funes, Leonardo. 1997. El modelo historiográfico alfonsí: una caracterización, Papers of the Medieval Hispanic Research Seminar, 6 (London: Queen Mary and Westfield College)

Funes, Leonardo. 200o. 'Dos versiones antagónicas de la historia y de la ley: una visión de la historiografía castellana de Alfonso X al Canciller Ayala’, in Teoría y práctica de la historiografía hispánica medieval, ed. by Aengus Ward (Birmingham: University of Birmingham Press), pp. 8-3I

Funes, Leonardo. 200I. 'Las variaciones del relato histórico en la Castilla del siglo XIV: el período post-alfonsí, in Estudios sobre la variación textual: prosa castellana de los siglos XIII a XVI 
(Buenos Aires: SECRIT), pp. I2I-I34

Funes, Leonardo. 2003. 'De Alfonso el Sabio al Canciller Ayala: variaciones del relato histórico', Memorabilia: Boletín de Literatura Sapiencial, ${ }_{7}<\underline{\text { https://tinyurl.com/vvh6r2c }>}$

Funes, Leonardo. 20I5. 'Estorias nobiliarias del período I272-I3І2: fundación ficcional de una verdad histórica', in Literatura y ficción: 'estorias', aventuras y poesía en la Edad Media, ed. by Marta Haro Cortés (València: Universitat de València), pp. I65-I75

García Gallo, Alfonso. 1950. 'El concilio de Coyanza: contribución al Derecho Canónico español en la Alta Edad Media', Anuario de Historia del Derecho Español, 20: 275-633

García González, Juan José. 2008. 'Formación, expansión y consolidación de Castilla', in Historia de Castilla: de Atapuerca a Fuensaldaña, ed. by Juan José García González (Madrid: Esfera de los Libros), pp. 2I-30O

García León, Susana. 1999. 'Un “Repertorio” de Leyes de Cortes del siglo XIV', Cuadernos de Historia del Derecho, 6: 325-413 <https://tinyurl.com/rj96450>

Gómez Moreno, Manuel (ed.). I92I. Introducción a la 'Historia silense' con versión castellana de la misma y de la crónica de Sampiro (Madrid: Junta para Ampliación de Estudios e Investigaciones Científicas-Centro de Estudios Históricos) $\left\langle\underline{\text { http:/ } / g_{0} \text {.uv.es/YfOLE42 }}>\right.$

Gómez Pérez, José. 1962. 'La más antigua traducción del Toledano’, Hispania, 22: 357-37I

Gómez Redondo, Fernando. 1998. Historia de la prosa medieval castellana, I: La creación del discurso político: el entramado cortesano (Madrid: Cátedra)

Gómez Redondo, Fernando. 200oa. 'De la crónica general a la real: transformaciones ideológicas en Crónica de tres reyes', in La historia alfonsí: el modelo y sus destinos (siglos XIII-XV), ed. by Georges Martin (Madrid: Casa de Velázquez), pp. 95-I24

Gómez Redondo, Fernando. 2ooob. 'La construcción del modelo de crónica real', in Alfonso X el Sabio y las crónicas de España, ed. by Inés Fernández-Ordóñez (Valladolid: Universidad de Valladolid), pp. I33-I58

Gómez Redondo, Fernando. 2013. "Los siete infantes de Lara: de leyenda épica a "exemplo" historiográfico', Cahiers d'Études Hispaniques Médiévales, 36: I37-I79 < $\underline{\text { htp://go.uv.es/ }}$ qDiyGq8>

Henriet, Patrick. 20I2. 'L'Historia Silensis, chronique écrite par un moine de Sahagún: Nouveaux arguments', e-Spania, I4 <https://doi.org/I0.400o/e-spania.2I655>

Hijano Villegas, Manuel. 2ooo. 'Narraciones “descoyuntadas” en la Castilla bajomedieval: la Estoria del fecho de los godos', in Teoría y práctica de la historiografía medieval ibérica, ed. by Aengus Ward (Birmingham: University of Birmingham Press), pp. 32-58

Jerez, Enrique. 2003. 'La Historia gothica del Toledano y la historiografía romance'. Cahiers d'Études Hispaniques Médiévales, 26: 223-239 〈https://doi.org/IO.3406/cehm.2003.2020 $>$

Kabatek, Johannes. 1999. 'Sobre el nacimiento del castellano desde el espíritu de la oralidad (apuntes acerca de los textos jurídicos castellanos de los siglos XII y XIII)', in Discursos y representaciones en la Edad Media, ed. by Concepción Company, Aurelio González, and Lillian Von Der Walde Moheno (México: UNAM; El Colegio de México), pp. I69-I87

Lacapra, Dominick. 20II. Representar el Holocausto: historia, teoría, trauma (Buenos Aires: Prometeo) 
Lacarra, José María. 1972. Historia política del reino de Navarra desde sus orígenes hasta su incorporación al reino de Castilla, 3 vols (Pamplona: Aranzadi)

Lacomba, Marta. 2009. Au-delà du 'Cantar de mio Cid'(Madrid: Casa de Velázquez)

Larrea, Juan José. 2005. 'El reinado de García de Nájera, entre el viejo y el nuevo orden: rey, barones e infanzones entre la monarquía isidoriana y la feudal', in García Sánchez III 'el de Nájera' un rey y un reino en la Europa del siglo XI, ed. by José Ignacio de la Iglesia Duarte (Logroño: Instituto de Estudios Riojanos), pp. I5 ${ }^{\mathrm{I}-72}$

Lindley Cintra, Luís Felipe (ed.). I951. Crónica geral de Espanha de 1344 (Lisboa: Academia Portuguesa da História)

Linehan, Peter. 1993. 'El siglo XIII, I: confianza', in Historia e historiadores en la España medieval (Salamanca: Ediciones Universidad de Salamanca), pp. 439-486

Maddox, Donald. 1986. 'Vers un Modèle de la communauté textuelle au Moyen Age: Les rapports entre auteur et texte, entre le texte et lecteur', in Actes du XVIIIe Congrès International de Linguistique et de Philologie Romanes, ed. by Dieter Kremer (Tübingen: Niemeyer Verlag), vi: $480-490$

Martin, Georges. 1992. Les Juges de Castille: Mentalités et discours historiques dans l'Espagne médiévale (Paris: Klincksieck) 〈https://doi.org/IO.3406/cehm.Ig92.2095>

Martin, Georges. 1997. 'L'Hiatus référentiel (Une Sémiotique fondamentale de la signification historique au Moyen Âge)', in Histoires de l'Espagne médiévale: Historiographie, geste, romancero (Paris: Klincksieck), pp. 43-56 <https://doi.org/IO.3406/cehm.I997.2I8I $>$

Martin, Georges. 20o8. 'Le concept de “naturalité” (naturaleza) dans les Sept parties, d'Alphonse X le Sage', e-Spania, 5 <https://doi.org/IO.4000/e-spania.IO753>

Martin, Georges. 2009. 'Mujeres de la Najerense', e-Spania, I 4 <http://dx.doi.org/10.400o/espania.I7990>

Martin, Georges. 20I2a. 'Ordoño Sisnández, autor de la Historia legionensis (llamada silensis): notas histórico-filológicas sobre un ego fundador', e-Spania $<\underline{\text { https://doi.org/IO.4000/e- }}$ spania.2I7II $>$

Martin, Georges. 20I2b. 'Después de Pidal: medio siglo de renovación en el estudio de la historiografía hispánica medieval de los siglos XII y XIII', in Literatura medieval y renacentista en España: líneas y pautas, ed. by Natalia Fernández Rodríguez, and María Fernández Ferreiro (Salamanca: La Semyr), pp. II9-I42

Martín Iglesias, José Carlos. 2009. 'Los Annales Castellani Antiquiores y Annales Castellani Recentiores: edición y traducción anotada', Territorio, Sociedad y Poder, 4: 203-226 <http:// go.uv.es/QcWO3Xm>

Martínez Díez, Gonzalo. 1993. Fernando III (1217-1252) (Palencia: Diputación Provincial; Editorial La Olmeda)

Menéndez Pidal, Ramón. 1929. La España del Cid, 2 vols (Madrid: Plutarco)

Menéndez Pidal, Ramón (ed.). r955. Primera crónica general: estoria de España que mandó componer Alfonso el Sabio y se continuaba bajo Sancho IV en 1289, 2 vols (Madrid: Seminario Menéndez Pidal; Gredos)

Miceli, Paola. 2003. 'El derecho consuetudinario en Castilla: una crítica a la matriz romántica de las 
interpretaciones sobre la costumbre', Hispania, 63.I: 9-27 <https://tinyurl.com/qoclxya $>$

Miranda, Sílvia. 20I3. Reconstituição do ms. L da 'Crónica Geral de Espanha de 1344’ (2a parte)

(Lisboa: Universidade de Lisboa) <https://tinyurl.com/t7okn8f $>$

Montaner Frutos, Alberto. 2005. 'La mora Zaida, entre historia y leyenda (con una reflexión sobre la técnica historiográfica alfonsí)', in Historicist Essays on Hispano-Medieval Narrative, ed. by Barry Taylor and Geoffrey West (London: Maney Publishing; MHRA), pp. 272-352

Nieto Soria, José Manuel. 1987. 'La monarquía bajomedieval castellana: ¿una realeza sagrada?’, in Homenaje al prof. Juan Torres Fontes (Murcia: Universidad de Murcia), II: I225-I237

Nieto Soria, José Manuel. I988. Fundamentos ideológicos del poder real en Castilla (siglos XIII-XVI) (Madrid: EUDEMA)

Nieto Soria, José Manuel. 1997. 'Origen divino, espíritu laico y poder real en la Castilla del siglo XIII', Anuario de Estudios Medievales, 27: 43-IOO $<$ https://tinyurl.com/ukcd4d2 $>$

Nieto Soria, José Manuel. 20o8. 'La Segunda Partida en los debates políticos de la Castilla del siglo xv', e-Spania <https://doi.org/I0.4000/e-spania.9993>

Nieto Soria, José Manuel. 20I7. 'Dos perspectivas de análisis sobre el crimen político desde la experiencia medieval: la tiranía y el envenenamiento', Clío \& Crimen, I4: 39-58 $<\underline{\text { https://tinyurl. }}$ com/scrvup $5>$

Orduna, Germán (ed.). 1994. Pero López de Ayala, Crónica del Rey Don Pedro y del Rey Don Enrique, su hermano, hijos del Rey don Alfonso Onceno (Buenos Aires: SECRIT)

Pérez de Urbel, Justo; González Ruiz-Zorrilla, Atilano (ed.). I959. Historia silense (Madrid: CSIC)

Pérez-Prendes Muñoz Arraco, José Manuel. 1989. 'Potestad real: señoríos y feudalismo en CastilaLeón', in En torno al feudalismo hispánico: I Congreso de Estudios Medievales (Ávila: Fundación Sánchez Albornoz), pp. 475-484

Real Academia de la Historia (ed.). I863. Cortes de los antiguos reinos de León y Castilla, 7 vols (Madrid: Imprenta Martín Rivanedeyra)

Rodrígez Porto, Rosa; Roselló Martínez, Sacramento. 20I7. 'The Redes Petristas Project: Mapping Petrista Networks Past and Present', La Corónica, I7.2: 39-52 <https://doi.org/IO.I353/ $\underline{\text { cor.2OI7.0003> }}$

Rochwert-Zuili, Patricia (ed.). 20Io. Crónica de Castilla (Paris: SEMH; Sorbonne; Les livres d'eSpania)

Rochwert-Zuili, Patricia. 20I7. 'Emoción, novelización y persuasión en la Crónica de Castilla', e-Spania, 27 <https://doi.org/I0.4000/e-spania.26583>

Rucquoi, Adeline. 1992. 'De los reyes que no son taumaturgos: los fundamentos de la realeza en España', Relaciones Estudios de Historia y Sociedad, I3.51: 55-IOO < $\underline{\text { http://go.uv.es/Vozbw79 }>}$

Ruiz Asencio, José Manuel; Herrero Jiménez, Mauricio (ed.). 1991. Crónica de veinte reyes (Burgos: Excelentísimo Ayuntamiento de Burgos)

Sáez, Carlos. 2005. 'Origen y función de los cartularios: el ejemplo de la España', Gazette du Livre Médiéval, 46: I2-21 <https://doi.org/I0.3406/galim.2005.I665>

Salgado Loureiro, José Ángel. 20ı6. 'La revolución sin revolución en la teoría política plenomedieval: el tiranicidio y la ausencia de acción colectiva en el Policraticus', Semata: Ciencias 
Sociais e Humanidades, 28: 225-244 〈http://doi.org/IO.I53O4/s.28.3749>

Sánchez-Arcilla Bernal, José. I994. 'En torno al derecho indiano vulgar', Cuadernos de Historia del Derecho, I: I3-24 〈http://go.uv.es/zulZb7O $>$

Sánchez-Albornoz, Claudio. ${ }_{197}$ 6. 'Un ceremonial inédito de coronación de los reyes de Castilla', in Viejos y nuevos estudios sobre las instituciones españolas (Madrid: Espasa-Calpe), II: I2I7-I247

Sánchez Alonso, Benito (ed.). I924. Crónica del obispo don Pelayo (Madrid: Imprenta de los Sucesores de Hernando)

Serrano y Sanz, Manuel. I9I9. 'Cronicón villarense: Liber regum', Boletín de la Real Academia Española, 6: 192-220

Soler Bistué, Maximiliano. 20ıo. 'Los usos del pasado: historia, derecho y narración en la Crónica de Pedro I y Enrique II de Pero López de Ayala y una colección de fazañas castellanas', e-Spania, Io $\langle$ https://doi.org/IO.400o/e-spania.20I64 $>$

Soler Bistué, Maximiliano. 20I5. 'Los nombres de la ley: identidad y autoridad en la fazaña castellana', Letras, 72: I55-I66 <https://tinyurl.com/vl8rnyf $>$

Soler Bistué, Maximiliano (ed.). 20i6. Libro de los fueros de Castiella y otros textos del manuscrito 431 de la Biblioteca Nacional de España (Buenos Aires: Incipit)

Ullmann, Walter. I96r. Principios de gobierno y política en la Edad Media (Madrid: Alianza)

Valdaliso Casanova, Covadonga. 20I2. 'Los rastros de la historiografía petrista en el siglo XV. El reinado de Pedro I de Castilla en la Estoria amplia refundida hasta 1455 y en la Refundición del sumario del despensero de la reina Doña Leonor de Aragón', in Estudios de literatura medieval: 25 años de la Asociación Hispánica de Literatura Medieval: 25 años de la AHLM, ed. by Antonia Martínez Pérez, and Ana Luisa Baquero Escudero (Murcia: Universidad de Murcia), pp. 919-927

Van der Walt, Carol Ann (ed.). r999. 'A critical edition of the Toledano romanzado’ (unpublished doctoral thesis, University of Birmingham)

Vindel Pérez, Ingrid (ed.). 20I6. ‘Crónica de I344: edición crítica y estudio’ (unpublished doctoral

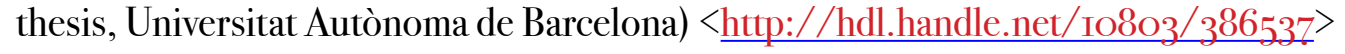

Ward, Aengus. 2002. 'La Estoria de los godos: ¿la primera crónica castellana?', Revista de Poética Medieval, 8: I8I-200

Ward, Aengus (ed.). 20o6. Estoria de los godos: Critical Edition and Introduction. (Exeter: Medium Aevum Monographs)

Zumthor, Paul. i989. La letra y la voz: de la literatura' medieval (Madrid: Cátedra) 